\title{
Mārginenii Sibiului: The Historical Geography of a Transylvanian Carpathian Community
}

\author{
Mircea Buza ${ }^{\mathrm{A}}$, Marioara Cojocariu-Costea ${ }^{\mathrm{B}}$, David Turnock ${ }^{\mathrm{C}}$ \\ Received: May 2009 | Revised: October 2009 | Second Revised: December 2009| Accepted: December 2009
}

\begin{abstract}
The paper profiles the evolution of a Romanian Carpathian community that has a long association with the country's German minority; with a sharp contrast between the Medieval period, when the Germans lived as a privileged group in the closed city of Sibiu (Hermannstadt) and its surrounding communities - such as Cisnădie (Heltau) - displacing the indigenous Romanians towards the higher ground, and the last century which has seen the Romanians establishing an overwhelming majority in all parts of Sibiu county. Stimulated to an extent by the German markets, the Romanian communities maximised the potential for a pastoral economy through transhumance systems which once extended well beyond the present limits of the Romanian state and supported a range of manufacturing and handicraft activities at home. Despite the erosion of these systems by steppeland colonisation and the logistics of transit (which now include EU animal welfare regulations) the vibrant communities of Mărginenii Sibiului continue to show a capacity for adaptation in harmony with the big city with which they now share a improved standard of infrastructure and a substantial tourist industry as well as ongoing participation in its labour market.
\end{abstract}

Key words: Carpathians, ethnicity, Sibiu, settlement history, tourism, transhumance

\section{Introduction: \\ The region and its significance}

The Romanian Carpathians are well known for the intensity of the pastoral life (Vuia 1964) and the commitment of the Romanians to this branch of farming ties up with the tradition of Dacian occupation of the high ground. This may give rise to exaggerated claims for permanent occupation well above the present levels of permanent settlement, but it certainly provides the basis for the colonisation of the more northerly parts of the Carpathians by 'Wallachian shepherds' who may provide an origin for the Lemko/Rusyn minorities in parts of Poland, Slovakia and Ukraine (Turnock 2003). Individual localities provide their own peculiar testimonies to a traditional mountain economy which is by no means eclipsed by the modernisation and diversification of the past century. However Mărginimea Sibiului offers particular attractions for a local study given the almost unique intensity of the pastoral life in this area, noticed by Emm. de Martonne and especially by L.Someşan: this certainly applied historically but still remains relevant today given the extent of the mountain pastures; while the retention of long-wave transhumance systems continued in the westernmost part of the area until very recently (Plates 1-2). The district comprises a cluster of localities at the contact of the Cindrel and Lotru Mountains with the Sibiu-Apold Depression. However while several settlements do lie right on the contact at 550-600m, four (Galeş, Râu Sadului, Rod and Tilişca) are situated in valleys at 600-750m (Plates 3-4) and another two (Jina and Poiana Sibiului) are 'sate de culme' lying even higher up (750-950m) on the gentlysloping 'Gornovița surface': the lowest of three peneplains (Plate 5). Here - as the saying goes - there is much sunshine and little snow compared with the valleys; although windbreaks are needed (hence the farmhouses have large courtyards into which carts can be driven) and the lack of water calls for storage tanks as well as the pumping of groundwater. The paper is primarily a work in settlement history but it also has an ecological content relating to the peneplains and the conservation of grasslands with high nature value (Jones 2007).

\footnotetext{
A Institute of Geography, Str.Dimitrie Racovița 12, 023993 Bucureşti Sec.2, România; e-mail: igar@geoinst.ro

B Department of Ecology \& Environmmental Protection, Lucian Blaga University, Str.Dr.lon Rațiu 5-7, 550012 Sibiu, Romania; e-mail: maria_costea@yahoo.com

c Department of Geography, University of Leicester, University Road, Leicester LE1 7RH, U.K.; e-mail: dt8@le.ac.uk

* Corresponding author: David Turnock, e-mail: dt8@le.ac.uk
} 


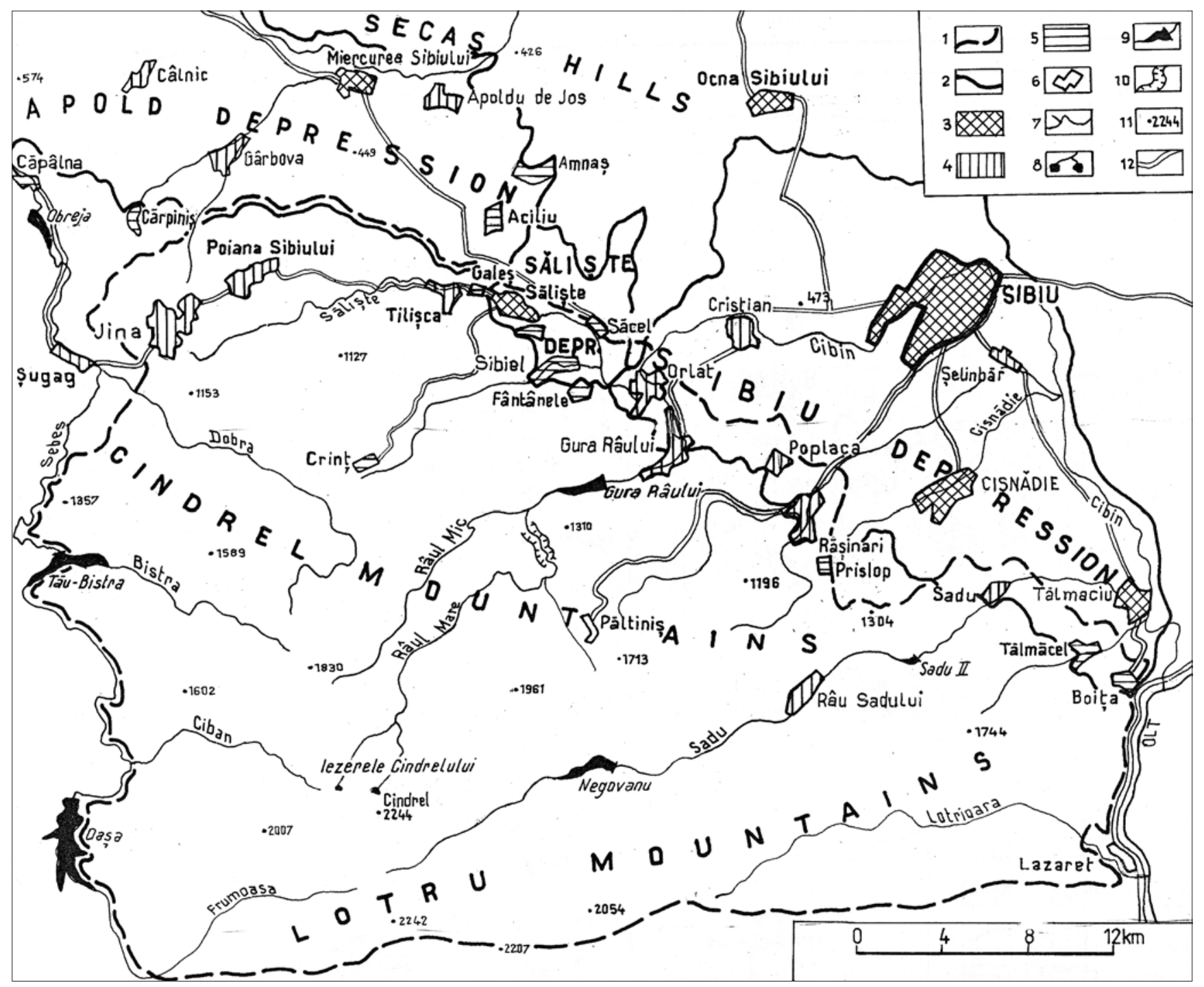

Figure 1. The district of Mărginenii Sibiului

In terms of today's administrative units (Table 1) the area includes six communes comprising single villages: Gura Râului dating back to 1476: the year of the earliest documentary mention (Ghinea 1996-8, II pp.126-8), Jina (1733), Orlat (1317), Poiana Sibiului (1532), Poplaca (1488), Râu Sadului (1850) and Sadu (1488). Some of these communes include outlying hamlets - e.g. Drăgăneasa and Fundu Râului in

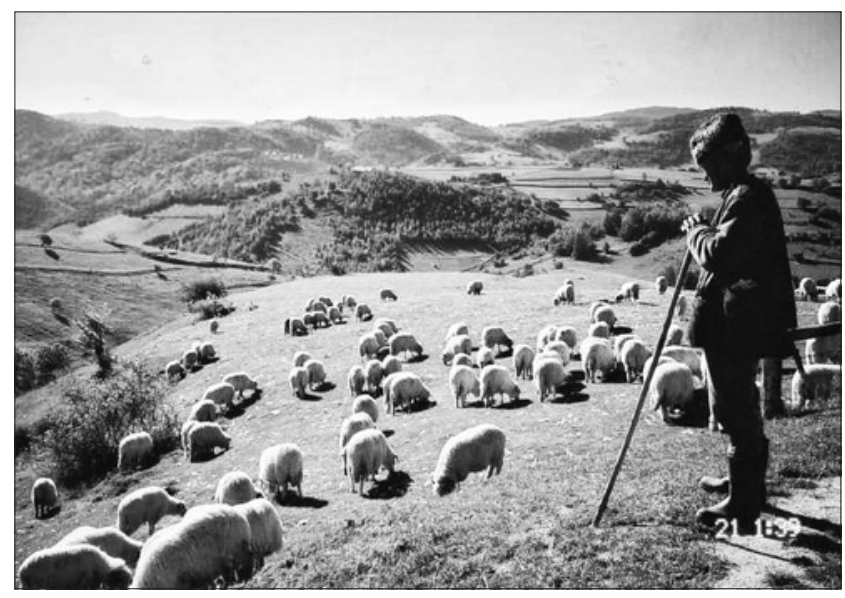

Plate 1. Sheep grazing in the Jina area 2003 (K.Urushibara-Yoshino)
Râu Sadului commune - which are not officially regarded as separate settlements. But two other communes do include a second (official) village: Prislop (no date) in Răşinari commune (1488) and Rod (also 1488) in Tilişca commune (1366). And there are two other communes (both now urban) that lie only partly in the study area. Sălişte (1354) - a town since 2003 -officially comprises ten units although only five Galeş (1383), Fântânele, initially known as Cacova or Cacova Sibiului (1366), Sibiel (1383) and Vale (1383) as well as Sălişte itself - are traditionally settlements of 'Mărginenii Sibiului'. Meanwhile in Tălmaciu (1318) - a town since 1989 - there are seven units of which only Boița and Tălmăcel (both 1488) are part of the district. The total number of official settlements is therefore 18 lying within 11 communes or towns. The settlements lie along river axes: the Cibin and Sadu (both tributaries of the Olt) with the latter of lesser importance embracing Sadu and Tălmaciu only. As regards population at the last census (2002) there are seven villages with fewer than 1,00o inhabitants:Râu Sadului 636, Rod 465, Sibiel 400, Vale 384, Galeş 331, Fântânele 252 and Prislop 243; five with 1,000-2,500: Sadu 2,472, Poplaca 1,779, Boița 1,517, Tălmăcel 1,224 and Tilișca 1,197; and six with over 2,500: Răşinari 5,286, Jina 4,073, Gura Râului 3,621, Orlat 3,271, Sălişte 2,830 and Poiana Sibiului 2,799. It is also worth 
noting that while Crinț is listed as a village in the urban territory of Sălişte it has no permanent population, consisting only of chalets, sheepfolds and summer houses, while Păltiniş is a substantial resort within Răşinari commune but is subordinate to the town of Sibiu.

The coherence of the area derives historically from a mutually beneficial association between the Romanian pastoralists and the Saxon (German) settlers who founded the commercial settlements of Heltau (Cisnădie) and Hermannstadt (Sibiu) which relied on the supply of raw materials based on the local pastures and forests (expanding in recent times into regular commuting for employment and services). Sibiu is known from 1190 as a German community near the Roman settlement of Caedonia (while other com-

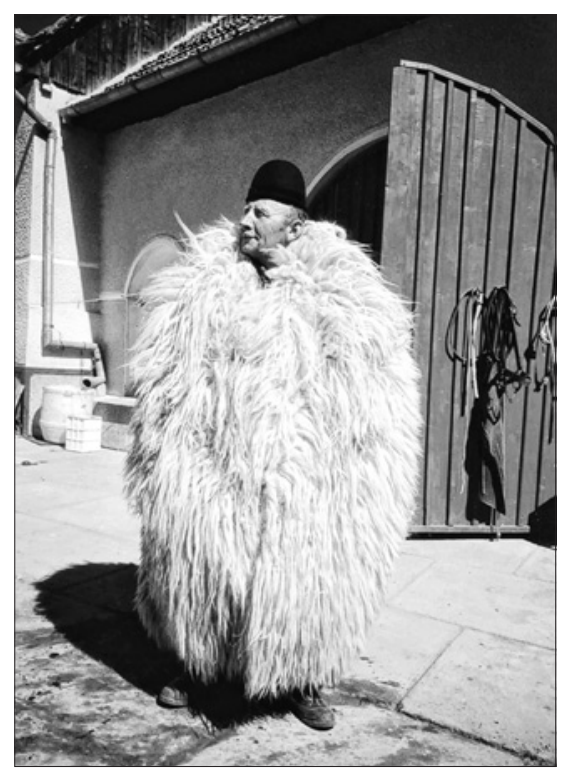

Plate 2. A Jina sheepfarmer wearing the traditional coat or ' cojoc' (S.Shirasaka) of German/Saxon settlement in the province) and accommodated the Saxon assembly: Universitas Saxorum. Hence the name of our study area as Mărginimea Sibiului (Conea, 1965) or 'Mărginenime', while the Romanians and/or Romanian settlements of the district are known as Mărginenii Sibiului. It is also worth adding that the area has some coherence historically in connection with the fourteenth-sixteenth century feudal territory extending from Fântânele in the east to Tilişca in the west but centred on Sălişte and known for a time as 'Ducatul Amlaşului' and, as already noted, the oldest settlements date to the beginning of this period, with Sălişte documented as Magna Villa Valachialis (Grecu 1990). Strongpoints are known at Sibiel nearby, through munities followed at Cisnădioara and Cristian in 1223, Salgo castle built in 1322 within the Amlaş territory: part Şelimbăr in 1327 and Şura Mare 1332). With craft guilds reported in 1376 and a school in 1380, Sibiu became the most important of the 'Siebenbürgen' (a grouping of seven castles and related settlements which formed the core of a chain in the in the upper Cibin valley at some $700 \mathrm{~m}$ altitude which also included Fântânele, Galeş and Tilişca. There was also a thirteenth/fourteenth century feudal castle at Răşinari while the 'Cetatea de Pământ' of Orlat se-

Table 1. Population 1857-2002

\begin{tabular}{|c|c|c|c|c|c|c|}
\hline \multirow{2}{*}{$\begin{array}{l}\text { Town or } \\
\text { Commune }\end{array}$} & \multicolumn{6}{|c|}{ Census Year } \\
\hline & $1857^{*}$ & 1880 & 1910 & 1966 & 1992 & \#2002 (ii) (iii) \\
\hline \multicolumn{7}{|c|}{ MĂRGINIMEA SIBIULUI** } \\
\hline Jina & 1960 & 2658 & 3471 & 4009 & 4348 & 407349.33 .96 \\
\hline Orlat & 1649 & 1658 & 1836 & 2953 & 3363 & 327152.62 .73 \\
\hline Poplaca & 2287 & 2315 & 2613 & 2123 & 1734 & 177949.62 .34 \\
\hline Răşinari & 6012 & 5232 & 5771 & 5774 & 5645 & 552951.32 .79 \\
\hline Râul Sadului**** & 0 & 0 & 900 & 1095 & 736 & 63645.81 .99 \\
\hline Sadu & 1626 & 1759 & 2143 & 2463 & 2561 & 247250.82 .14 \\
\hline Sălişte & 14528 & 11833 & 11378 & 7937 & 6103 & 579551.01 .79 \\
\hline Tălmaciu & 3479 & 3719 & 11549 & 9261 & 9369 & 883750.32 .79 \\
\hline Tilişca & 4431 & 3401 & 3266 & 2161 & 1899 & 166251.31 .68 \\
\hline Total & 42714 & 38333 & 49825 & 44548 & 42579 & 4042450.72 .56 \\
\hline \multicolumn{7}{|c|}{ ADJACENT URBAN AREAS } \\
\hline Cisnădie & 3207 & 4078 & 4028 & 14979 & 17807 & 1564851.53 .46 \\
\hline MiercureaSibiului & 4160 & 4835 & 5953 & 6581 & 4161 & 406350.22 .63 \\
\hline Sibiu & 22212 & 28515 & 45772 & 118581 & 177561 & 16334052.61 .03 \\
\hline Total & 29479 & 37428 & 55753 & 140141 & 199529 & 18305152.51 .26 \\
\hline Grand Total & 72293 & 75761 & 105578 & 184689 & 242108 & 22347552.11 .48 \\
\hline
\end{tabular}

* 1857 data includes 2898 persons absent from Mărginimea Sibiului (2088 from Sălişte and Tilişca) but the adjacent urban areas should also include 2124 persons staying temporarily.

** Data relates to the whole of the communes/towns listed including some areas outside the traditional limits of the region (likewise for Tables 2-4)

***Sibiu figures include Cristian and Şelimbar. Râul Sadului commune is known from 1850 but its population could have been included with Răşinari in 1857 and 1880 since this was the base for pastoralists using the higher sections of the Sadu valley.

\#2002 figures also include (ii) the percentage of the population female and (iii) the population below 30 years of age as a multiple of the over 60 s.

Alternative names for communes/villages are: (a) in German - Gallusdorf (Galeş); Winsberg (Orlat); Gonczesdorf (Poplaca); Städterdorf (Răşinari); Grossendorf/ Selischte (Sălişte), Talmesch (Tälmaciu); and Tilischen (Tilisca); (b) in Hungarian - Szebenkákova (Fântânele); Szebengálos (Galeş); Guraró (Gura Râului); Zsinna (Jina); Orlát (Orlat); Rasinár (Răşinari); Rioszád (Râu Sadului); Ród (Rod); Cód (Sadu); Szelistye (Sălişte), Szibiel (Sibiel); Nagytalmács (Tălmaciu); Tilicske (Tilisca); and Vále (Vale).

Sources: Census data: Romanian census data including Geography Institute (Bucharest) calculations for 1910 and Rotariu et al. 1997; 1998 for 1857/1880. For further basic data see Badea et al. 1971 and Ghinea 1996-8. 


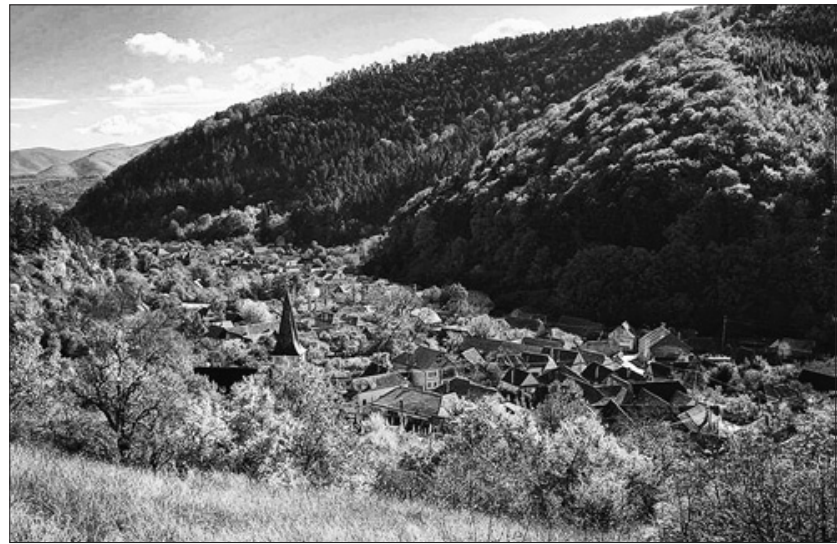

Plate 3. The village of Galeş situated in a small depression (M.Cojocariu-Costea)

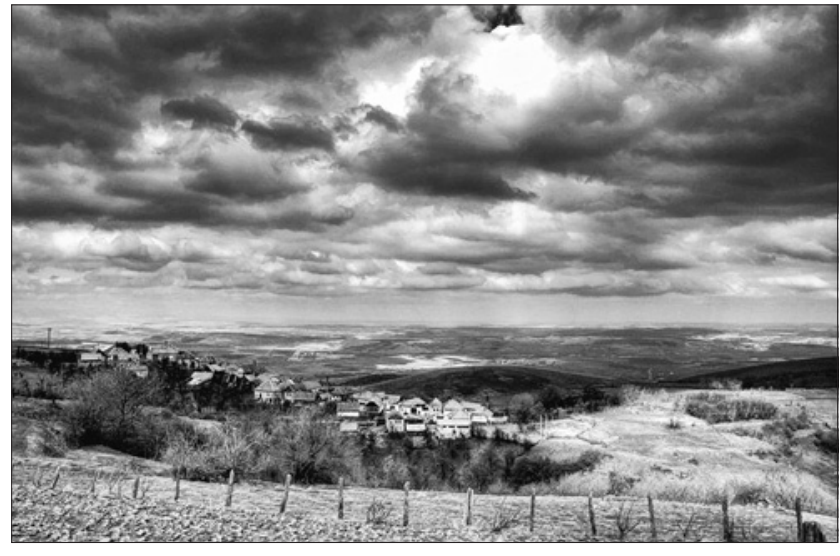

Plate 5. The plateau village of Poiana Sibiului (M.Cojocariu-Costea) cured the contact between the plain and the lower beech forest zone with the greatest economic potential.

Reference should also be made to the Habsburg administration in the early modern period which highlighted the strategic significance of the frontier with the principality of Wallachia, then under Ottoman suzerainty. Indeed in the eighteenth century (1762) Empress Maria Theresa established a frontier regiment ('regiment de graniță') at Orlat - where the hreadquarters building of 1763 remains and this had a particular relevance for Jina (as well as some other villages in Alba, Braşov and Hunedoara counties) which received a large land endowment. But the physical factor has

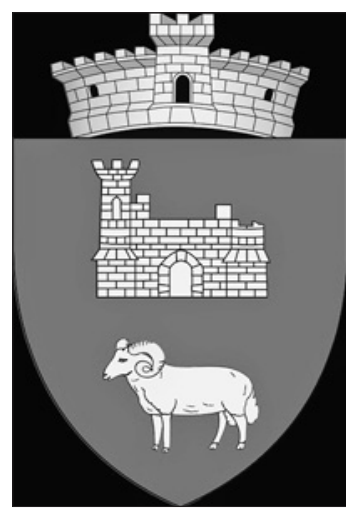

Plate 4. Emblem for the commune of Tilişca (M.Cojocariu-Costea) close familiarity with the Carpathian terrain and knowledge of the historical detail through documentary study as well as secondary sources linked with a doctorate thesis. The ecological aspects have been thoroughly researched through fieldwork (e.g. Buza 2004) and relations with the German community have been traced through works such as Lotreanu (1988). The paper is organised into three main sections. The first deals with the period pre-18oo covering the first centuries or interaction between the Romanian and Saxon communities but also an earlier period (without documentary sources) for which there has been much speculation over the settlement and migration of the Romanians and their Dacian antecedents. Our view significance with regard to the Cindrel Mountains (Buza \& Fecsi 1972, 1973, 1983) through the succession of peneplains giving rise to smooth mountain summits: "well-levelled summits slope almost radially down to $750-800 m$ above the depressions" (Badea \& Buza 1994, p.110). This has favoured human penetration as have the valley systems, especially the Olt and its tributaries where there is now a well-developed road system. These characteristics also apply further west in the Şureanu Mountains but Mărginimea Sibiului is arguably more remarkable in terms of its human geography through the intensity of development linked with the industries of Sibiu. The Romanians showed great persist ence in opening up a band of settlement and agriculture between 500 and 90om (not to mention summer grazings in the high mountains) by extending networks based on the primary ('obst') communities of the Cibin valley at Apold, Săliste and Răşinari where secondary woodland now covers part of the land originally cleared. There was also massive forest clearance to provide pastures and hay meadows with temporary huts ('colibele') and grazing stations ('stâne'). This was not without environmental consequences but the gradual rate of clearance and the use of distant pastures helped to moderate erosion (Buza 200o).

Our paper is written as a historical narrative tracing the economic and social evolution of this remarkable community with physical resources based on the high mountain surfaces and economic opportunity arising through commercial involvement with the Saxons. Our research team has is against any notion of major settlement shifts to the high surfaces during the Dark Age 'invasion period' or earlier (Turnock 2003). The following section on the eighteenth and nineteenth centuries has much richer documentation (including census returns) for tracing the the expansion of the Romanian community manifested through a remarkable development of long-wave transhumance researched by Dragomir $(1925,1938)$ and more recent writers. While continuing to supply raw materials to Sibiu the Romanians also developed a range of local industries, with a special reputation for their textile production. For the twentieth century we see continued dispersal of Romanian enterprise across the Carpathians (especially Wallachia) contemporaneously with constraints on long-wave transhumance. But at the same time the Romanians were able to penetrate the old Saxon citadels to expand the industrial base and gradually establish a Romanian majority alongside remants of the Saxon community which is still highly influential in the life of the city. For this period we offer a much richer statistical base and substantial policy input.

\section{Early settlement: Prehistoric and medieval}

As regards early settlement Neolithic (Turdaş) cultural vestiges have been found at Tărtăria (Sălişte) while a Neolithic axe has been found near Răşinari. Tilişca is outstanding for the Bronze/Dacian settlement discovered on Dl.Cățănaş 
in 1959-60: fortified with an earth ditch and two stone/brick towers. But Giurcăneanu (1988, pp.254-6o) also refers to Neolithic settlement at Boița, Fântânele and Tilișca; also the Bronze/Iron Age sites at Răşinari and Dacian/Roman vestiges at Boița and Rod. There seems little doubt that the Romans found the Dacian tribes effectively occupying the Carpathians, for the terrain in this area offers extensive elevated surfaces for pastoralism. However, while the Dacian sites in the Orăştie Mountains point to a presence on the the highest surfaces, permanent settlement at these altitudes remains unproven. Migrations from the east transformed the political and ethnic geography of East Central Europe but significantly did not bring about the same radical change in the Romanian Carpathians. The situation during the occupation by the nomadic Petchenegs is by no means clear but it is believed that while the invaders imposed tribute on the indigenous population the regime was basically one of cohabitation ('conviețuirea') (Irimie et al. 1985, p.61). A pastoral farming system was maintained with several mountains named after the invaders who are referred to in documents as 'bisseni': Muntele Başinău (1963m) near Cristian - as well as 'Dealul Băşinău' which occurs at Jina and also near Sibiu - and several instances where the name Basarab appears; pointing not only to the influence of the invaders but also the uninterrupted occupation of the area by Romanians (Ibid). Indeed it was the invaders who were assimilated although they imposed some influence on the Romanian language.

There has been some speculation over the survival strategy of the indigenous population especially with regard to settlement since insecurity may have prompted some significant changes. Buza (1974) refers to a temporary adjustment ('parasire temporară') involving retreat to higher and safer places ('locuri mai ferite') probably within the forested zone. But it is likely that the relatively modest peasant strongholds established by larger agriculturally-based communities - 'obştile săteşti libere', standing close to the present-day settlements - offer the best clues to the Medieval security system. Because change was also taking place (independently of the strategic situation) by way of transition from dispersed settlement in the Dark Ages - the Thracian-Illyrian hamlet or 'cătun' established by family groups - to the nucleated village (Buza 1981). Consolidation of rural settlement could have resulted in withdrawal from some hamlets on the higher ground; producing a downward movement from the hills to the valleys suggested by evidence of former spade ('sapa') cultivation on mountain slopes that are now wooded. However it is possible that the older redundant settlements could have found a new function as pastoral outliers - 'colibele' and 'bordeiele' (typically with closed polygonal structures) - related to the seasonal use of high grazings on the basis transhumance (Irimie et al. 1985, p.65). Thus, in the case of Sadu we have 'La Curățele' and 'La Bordeie' (shelter) standing on the higher ground above the village core close to the Sadu river (Ibid, p.74). However consolidation did not always involve an altitudinal shift because at Sălişte the old hamlets of Brata and Steaza are components of the present settlement whose great age is testified by the element 'silişte' which applies to the older settlements.
Much more substantial was the impact of the Magyars (Hungarians) who conquered Pannonia in the ninth century before embracing Christianity as the ideology of a state that extended its dominion over adjacent territories including Transylvania which they sought to defend against further invasions through a feudal regime imposed in the tenth and eleventh centuries. Of course there is little reliable information on our study area but we hear of the campaigns by Ladislau as early as the eleventh century which helped to disperse the Petchenegs who disappear from the historical record in 1241 with the arrival of the Tatars. The development of feudalism (superseding the regime of free 'obst' communities) ín the tenth/eleventh centuries cannot be unrelated to security issues and we find some evidence of a coordinated defence system along the edge of the Cindrel and Făgăraş Mountains (Săsciori to Avrig) including installations in our area associated with the 'ducat' of Amlaş. Significant here was Salgo fort (dating to 1322-1366 as already mentioned) which was built by the communities of Cacova (now Fântânele), Galeş, Sălişte and Sibiel: it recalls the Dacian castle at Tilişca (from the second and first centuries BC) that was part of a system developed around the Orăştie Mountains. Responsibility for defence later passed to the towns which came to exercise feudal authority and in the fifteenth century we hear of the Sibiu 'seat' or 'scaun' to which the 'scaunele româneşti' of Miercurea, Săliste and Tălmaciu were subordinate. But it is also clear that the threat of further incursions from the east prompted an invitation for Saxons to settle in privileged communities as 'guests' (hospites) and consolidate the defence of the province - especially during the reign of King Geza II (1141-1166) when the eastern and southern borders were exposed - and contribute to economic development of a wider multicultural region. The event was of profound significance in creating a historic landscape of Saxon villages to complement the established Romanian system (Akeroyd 2006).

Several new settlements took root on the more fertile ground of our area where Sibiu was established in c.1150 on the $2-25 \mathrm{~m}$ terrace of the Cibin, followed in 1204 by Cisnădie (Heltau) on an extensive floodplain closer to the Cindrel Mountains. They forcibly occupied the most fertile depressions and the lower hills, evidently displacing the Romanians towards the higher ground, although there is little detailed documentation. However, there is little doubt that Cisnădie was planted on Romanian land, while the need for water power gave the settlers an interest in the Sadu valley where the Romanian 'obşt' and 'cneaz', though not displaced, became subject to Cisnădie's feudal authority. The evidence suggests friendly 'sădenii-cisnădienii' relations but feudal obligations are made clear in a document of 1646 naming Romanians as 'iobăgii' (feudal dependents) when Gheorghe Rackoczi gave the Saxon community exclusive rights. New settlements were still being established at this time as Romanians moved towards the higher ground - e.g. from Dobârca near Miercurea Sibiului to Valea Mare (Poiana Sibiului) first mentioned in 1488 (as already noted) and from Apoldu de Sus to Rod - in response to German pressure in the Apold and Sibiu depressions, with documentary evidence of the legal struggles by the Romanians in Gura Râului and Orlat to resist the Saxons of Cristian. But on 
the whole the legacy is primarily one of peaceful coexistence and reciprocity both in this area and in other parts of southern Transylvania (Moga 1944, 1973). And it is from these early Medieval contacts that a firm historical outline becomes available as the Mărginenii shepherds evidently maintained close commercial ties with the Saxons and supplied their cloth factory in Cisnădie; which in turn accelerated development in the Romanian villages (Conea \& Badea 2004). In this way Mărginenii Sibiului provides a credible model for a dynamic pre-capitalist Balkan-Carpathian economic system ('viața economică de tip primitiv carpatic-balcanic') (Irimie et al. 1985, p.61).

Agriculture involved cereals (barley and rye) with vegetables and textile crops based on cultivation by both plough and spade ('sapa'). There was also fruit growing and apiculture; complemented by handicrafts based on wood, leather, textiles and milk. By the fourteenth century water power was being harnessed and we hear of the water mills: 'mori de apă'; not to mention the local expressions 'vâltoarea' and 'şteaza' - with the latter cropping up as the name for small steams at Răşinari and Sălişte as well as as a pair of hills (Şteaza Mică/Mare) at Jina (Irimie et al. 1985, p.66). The mills were used for fulling ('pive'), hammering ('ciocanele'), sawing ('ferestraele') and breaking stone and ore ('steampurile'), while oil/grape presses and small brandy distilleries ('alambicurile de alcool') were also operating (Ibid, p.69). Sheep grazing systems based on transhumance are documented at Raşinari from the fourteenth-fifteenth centuries (though they werte probably very much older) and extended certainly far as the Lotru valley in the south, with the name 'staul' (stable) - from the Latin 'stabulum - and later 'stâna' as a useful indicator of the spatial extent: e.g. 'Pădurea Staulelor' at Poiana Sibiului and 'La Staule' at Jina where documentation comes a little later. Altitudinally it is possible to envisage clearings ('prisăci') up to 1,200-1,40om for hunting as well as grazing with 'nedeia' markets on the watersheds where the phrase 'târguri de două țări' - markets for two lands - indicates a rationale whereby 'central places' on the high ground could unite people on either side of the mountains (Ibid, p.64). Studies of the local toponomy (Vlad 1996a, 1996b) highlight the importance of pastoralism and also deforestation indicated by names such as Arsă, Pleşu/Pleaşa, Poiana and Runc. However, as already established, the presumption that people were living permanently at such levels is not supported by archaeology or by documentary evidence.

\section{Modern settlement: The eighteenth-nineteenth centuries}

The research of Irimie et al. (1985) in this zone suggests that the great pastoral enterprise grew to a peak during this period. Quite apart from the limited local fodder supply (even after centuries of deforestation) the fact that it snows too soon in winter - 'ninge iute': a quote attributed to Ioan Bratu of Tilişca (Constantin 2003b, p.97) - had serious implications for the survival of the sheep which, although tough are liable to 'give up' to the coldness of winter. Hence sig nificant enlargement of flocks became dependent on milder wintering conditions. So Mărginenii shepherds made reg ular visits to Banat, Debrecen and the Giurghiu-Căliman area of north Transylvania, while sheep also passed southwards - as they also did from the Kronstadt (Braşov) area - en route to Ottoman territory after the Treaty of Passarowitz (1718) opened the way for the wintering of livestock in the Lower Danube valley and Dobrogea. This involved a journey of up to $300 \mathrm{kms}$, taking 12-14 days. In this way itinerant shepherds would set up a traditional pastoral outlier - 'un fel de enclave zootehnice tradiționale' (Ibid p.96) - in the distant steppes. Payment of tribute ('beilic') to the Turks secured 'teschkere': the right to roam at will around Balcic, Bazargic as well as Batova ('the valley without winter'). In March they would return home, taking advantage of the Zimnicea floodplain grazings en route. Alternatively the East Carpathian customs posts of Ghimeş and Oituz gave access to the Jijia valley of North Moldavia; also Bessarabia and even lands beyond the Nistru or Dniester (Dragomir 1925, 1938). Pastoralism was stimulated by population growth and fiscal pressures, which also encouraged some 'Ungureni' (Romanians from Hungarian territory) to settle permanently on the Ottoman side of the mountains and Constantin (2004, p.98) highlights the remark of Donat (1966, p.293) that some 80 new villages had been founded by Transylvanian pastoralists in the southeastern Carpathians by the end of the eighteenth century.

Meanwhile at home there was further deforestation linked with more intensive pastoralism based on an in creased hay harvest, along with cultivation up to $900 \mathrm{~m}$ at Jina (where border modifications in 1766 gave much more land to the local community) as well as Rod and Poiana Sibiului. With some terracing on sloping land (especially north of Poiana Sibiului), agricultural progress centred on the potato crop (grown at heights of 1,30om around shepherds' huts) and there was increased attention to fruit growing and beekeeping linked with local processing (e.g fruit drying) for subsistence in winter. At Sadu sheepbreed ing made use of the 'caracul' breed from Dobrogea and the 'țigaie' from Moldavia. Meanwhile, the larger villages like Răşinari and Sălişte (which supported their own business schools) took on more of an industrial and commercial character while smaller settlements without supplementary non-agricultural resources often went into decline by the end of the nineteenth century. There were some specialist trade organisations, seeking greater trade efficiency, like the 'pieptănarilor' (carding masters) at Galeș in 1856 and 'cojocarii' (sheepskin coat makers) at Sălişte in 1869. 'Societatea de Păstrare şi Împrunut din Răşinari' (1867) was actually a small commercial bank, serving local agricultural interests by handling deposits and loans for new business, which avoided the Saxon monopoly on banking in Sibiu. Increased wool production (arising from the expansion of the transhumance system) had positive implications for local industry as well as the supply of raw material to Saxon businesses. In addition, fulling was carried out for weavers from an extensive area across southern Transylvania who forwarded their goods (Irimie et al. 1985, p.256). Perhaps most remarkable were attempts to develop an iron industry at the end of the eighteenth century when Daniil Bârsan of Sălişte brought in a specialist from the Beiuş area of Bihor to open up a rural forge - 'un mare atelier de fierărie' 
- in order to make ploughs and other equipment sold in Transylvanian towns and also in Wallachia, not to mention the needs of locksmiths, wheelwrights and other crafts. In the late nineteenth century there were around 50 smithies ('fierari') in the district - including eight in Gura Râului, seven each in Poplaca and Sălişte, four each in Tălmacel and Tilişca and three each in Sadu, Răşinari, Orlat and Sibiel - cumulatively producing farm tools like a factory. Some were still working in the 1930 (Ibid, p.257).

In spite of centuries of deforestation there was still plenty of beech and resinous (fir/spruce) woodland exceeding $80 \%$ of the land at Jina, $70 \%$ at Orlat, $60 \%$ at Boița, Gura Râului, Raşinari and Sibiel and 50\% at Poplaca and Tălmacel (but only $40.0 \%$ at Râul Sadului, 36.4\% at Sălişte, 30.6\% at Tilisca, $21.1 \%$ at Galeş, $15.7 \%$ at Vale and $11.4 \%$ at Rod) (Irimie et al. 1985, p.231). So collecting firewood and timber for manufacturing ('lemne de lucru') was an important task, especially in winter and spring. In Jina and Orlat frontier associations ('composesoratele grănicerești') operated from the seventeenth century until 1948. With the stimulus of local demand and export of sawn timber to Wallachia, systematic exploitation was evident from the first half of the nineteenth century through local cooperative organisation ('întovărăşirea mărginenilor') with floating on the Cibin and Sadu downstream from the Gura Râului and Râu Sadului areas (the latter settlement first mentioned in 1850): construction timber could be supplied as rafts consisting of tree stems roped together ('plute închingate'), with a simple tiller ('fel de protap') for navigation,while casual floating ('plutăritul liber') was used for firewood. Wood was an important business at Sadu when sheep were exchanged in winter for such essentials as carts and plough-shafts (Lotreanu 1988, p.73). The first capitalist logging companies (who introduced steam powered saws or 'gatere') arrived in the Sadu area in 1906 and worked the resinous timber on the two sides of the valley, each with its own light railway. The first, known as OFA, was a Swiss consortium that provided an office and housing for its employees in Tălmaciu near the Sadu/Cibin confluence. However its railway was poorly constructed with fragile track that caused many derailments and serious accidents until workers insisted on an adequate braking system. Wood was transferred to the standard gauge railway at Tălmaciu and taken to Sibiu. A second company arrived in 1908 (Feltrinelli from Italy - a name still used for one of the local forests) and built a sawmill between Tălmaciu and Veştem, served by a well-built railway that set a standard for the first.

Great reliance was placed on water power. The water-powered sawmill ('joăgar') originated in the sixteenth century but the number increased rapidly in the eighteenth. The 'joagăreni' worked on the cutting, transport and processing of wood, especially at Gura Râului, Răşinari and Sadu (with processing at Boița and Tălmaciu where joiners and producers of wooden roof tiles were well represented). In 1844 there were 960 'joagăre' in Transylvania of which 200 were in 'mărginene' villages (a third in Gura Râului) owned by cooperative groups or 'întovărăşiţi' (Irimie et al. 1985, p.283). New mills were still being built in the last quarter of the nineteenth century: 11 in Răşinari alone (Ibid, p.232). The use of water power reached the highest levels at this time with fulling/wash mills, cornmills and sawmills totalling 65 at Gura Râului compared with 10-20 at Orlat, Răşinari, Rod, Sadu and Tilişca. Building these installations was a considerable labour in itself, involving not only the mills but also the feeder canals and ponds known as 'jilipuri' at Râu Sadului and 'iazuri' or 'scocuri' at Gura Râului. Meanwhile a limited number of cornmills were needed, while the textile industry required the multiplication of fulling mills ('pive') and wash mills ('vâltori') especially at Sălişte, Sibiel and Tilişca. Corn and fulling mills were usually built within the village perimeters for security, whereas the sawmills were more scattered in order to economise on transport. At the beginning of the twentieth century there were still 18 sawmills in the village of Gura Râului plus another 20 towards the mountains.

The period was one of substantial population growth. Incomplete estimates for the period c.1700-1850 (Buza 200o) suggest a rapid increase averaging $2.4 \%$ per annum whereas census returns for the period 1857-2002 show a decline of $-0.03 \%$, although the adjacent urban areas (mainly Sibiu) show growth averaging $3.6 \%$ per annum and the overall figure is $+1.4 \%$ (Table 1). Population growth was a factor in the building of chuches in the eighteenth century: Poiana Sibiului in 1730 (a wooden church using fir beams), Răşinari in 1758 on the site of an earlier fourteenth century church; Poplaca in 1793, Orlat in 1794, Jina in 1796 and Sălişte in 1798 (using materials of a sixteenth century monastery closed in 1788) as well as Sadu and Tilişca of unknown date. However this was also an era of enlightenment when Andrei Şaguna (1809-1873), as the Orthodox Bishop of Sibiu, encouraged a wave of new construction in line with trends in Wallachia with which closer economic ties were being established. The physical growth of villages may be considered in the light of research at Poiana Sibiului revealing a sixteenth century axis of development running roughly eastwards along Valea Radei from the present village centre with its Piața de Vadu. Eventually, the inconvenience of excessive linearity, coupled with the risks of flood, pushed eighteenth century development on the the ridges ('delnițe') then lying to the north (Pe Dealu and Pe Capu Dealului with a market place of Piața Târgului) and also a church square: Piața Bisericii, with a wooden chuch in 1779 (Possa \& Mihalik 1966). There was much more expansion southwards however: Hodorul de Jos/Sus close to the centre and Cârnu and Valea Lupați further away. The expansion of transhumance in the nineteenth century then correlates with the development of the western sector of the village: starting with Vadu, along the Jina road, followed by Grădini and Pe Vlaşin on the 'delnițe' to the south and finally northwestwards to Pe la Arini: the last 'delnița' to be developed (an area also used for growing vegetables on terraced ground). The net result is a butterflyshaped layout with an east-west extent of some three kilometers, with only limited expansion northwards because of the steep scarp whereas there is a more gentle rise over 6oo-1,00om below Vf.Ciuha $(1,064 \mathrm{~m})$. But a north-south extent of about one kilometer is constrained not only by a steep scarp to the north but also by the high wooded hill of Ghilghiu (940m) immediately south of the centre, though there is a row of farmhouses (Pe Curătură, indicating a clearing) in the narrow depression between Ghilghiu and 
the next hill (Vf.Pietriceaua 974m). A large centrally-placed market was provided at Piața de Vadu early in the nineteenth century and a new church followed in 1836. A choir formed in 1908 and constituted a significant social and cultural activity.

Growth evidently eased in the late nineteenth century as transhumance became constrained through cultivation of the steppes from the 1860 s and a particularly hard winter in 1875; while tighter border controls (preventing entry to into Bulgaria in 1879) made the Danube the effective limit. Customs wars between Romania and the Habsburg Empire broke out during 1885-91 when Romania's interest in protecting domestic industry affected her agricultural exports and resulted in less favourable border regulations. Some shepherds moved on to work seasonally in Bessarabia with the flocks of large landowners. They travelled via Bistrița and Bucovina, while returning with payment in wool - for use in the textile industry at home - via the more circuitous route through L'viv, Debrecen, Oradea and Cluj (avoiding Romanian customs duties by passing directly from Russian to Habsburg territory). But the wool road ('drumul lânii') running through the Eastern Carpathians via the Trotuş valley and Braşov provided the opportunity of picking up salt on the way. Some pastoralists pushed on to the open spaces of Crimea and Caucasus (heading eastwards from Sulina) for a more congenial environment avoiding the hard winters and dry summers in Bessarabia and reaping good profits for a ten year absence from home.

Another late nineteenth century strategy was to give up sheep rearing and turn to itinerant peddling ('comert ambulant') selling locally-produced goods - and others too - along various familiar 'wool roads': (a) northeastwards through Transylvania to Târgu Mureş, Bistrița, Suceava and Černivci (Cernăuți); (b) eastwards through Braşov and the Oituz Pass to Tecuci and thence towards the Black Sea coast via Galați and Ismail or else to Chişinău and Tighina; (c) southwards to the Danube at Turnu Severin, Calafat or Turnu Măgurele (following the river downstream to Cernavodă in the latter case); or (d) southeastwards along the edge of the Făgăraş Mountains to Piteşti and Bucharest. While the women did not normally go beyond the limits of Transylvania, the men would travel down the Olt valley to the Danube, perhaps with 60-70 carts setting off at the same time. The Comşa business in Sălişte was one of the more important. At the same time there was some permanent settlement along these routes where the 'Ungureni' typically formed distinct settlements apart from the indigenous 'Pământeni' (Bugă \& Dobre 1996, p.265). Many moved into Transylvanian towns, such as Bistrița and Târgu Mureş to the north and Hațeg and Petroşani to west, but others crossed the frontier into Oltenia to set up businesses in the towns of Râmnicu Vâlcea and Slatina or in such rural areas as Novaci, Polovragi and Vaideeni where water power could be harnessed. They also settled along the Bessarabian routes, including Brăila, Galați, Falciu and Huşi, while some found their way to Dobrogea (generally remaining in their adopted settlements after the post-World War One unification of Romanian territories) and a few were able to emigrate to the United States. However, while population declined on the whole after 1857 , there was some growth during 1880-1910 though expansion of wood processing at Tălmaciu although there may also have been higher natural increase as well.

\section{Romanian-Saxon relations}

An interesting question at this time is the nature of contacts between the Romanian and German communities. Although the latter were privileged it should not be as sumed that the relationship was one-sided. There can be lit tle doubt about the role of the Mărginenii in supplying the Saxon towns: not only with wool and timber but also stone from Răşinari and lime from Orlat. The water supply function is interesting and follows a detailed study by Haşeganu (1942). Sibiu depended heavily on the Cibin (Zibin) valley in both economic and strategic terms (Figure 2). A lateral canal was excavated parallel to the main stream as early as the fourteenth century and was known variously as Valea Mare (Grossbach), Valea Turnului (Thurnbach) and Valea Morii (Mülbach) with the aim of generating a modest amount of power for the emerging industrial axis. The canal helped drain the floodplain which became more widely available for settlement long before dykes were built in the seventeenth century. The power of the Cibin was supplemented by flow from a higher level involving a small tributary stream known as Valea Cârlova or Pârâul de Mijloc (Mittelbach) connected by means of Canalul Strezii/Streju (Trinkbach). Indeed the defences for the town's administrative military-commercial complex - situated on higher ground at some 43om (between the two streams) where deep wells were sunk - consisted not only only of walls but also of ponds created alongside both streams as well as some larger lakes (e.g. Croitori, Tăbăcari) which had to be carefully maintained. Meanwhile a wider canal system of 'vâlcele' or 'rigole' supplied a network of cisterns for drinking water, firefighting, street cleaning and other needs. However water was not always fit for drinking due to freezing as well as pollution by heavy rain or garbage: epidemics were still oc curring in the seventeenth through poor hygiene. The water system continued to evolve and the upper level spawned its own (short) lateral canal - Canalul Şcolilor (Schülbach) in 1829, relating to the swimming school (Şcoala de Innot) - which supplied a small water wheel while a brewery was established in the locality. There was also a flood relief channel from Dumbrava known as Părăul Săpanului (Seifengraben) and subsequent regularisation produced a new generation of mills to process cereals and timber, while removing some old channels and small infilled storages that became irrigated vegetable gardens ('grădini de zarzavat') from the eighteenth century; meanwhile the park of 1879 occupied a former sawmill site. A modern water supply system was established during 1886-94 taking water from springs in the Dumbrava Forest; supplemented by a major pipeline extension project started in 1908 to Păltiniş to tap numerous springs in the locality as well as several headwaters of the Cibin: Şanta/Şteaz in 1910, Dăneasa in 1922, Cotorăşti/Cotoreşti in 1925 and Mitropolie in 1927 at altitudes of some 1,50om (Figure 3). The local streams thus lost their water supply function and disappeared by the early twentieth century, though the upper section of the Pârâul de Mijloc remains in the shape of the Dumbrava fishponds. 


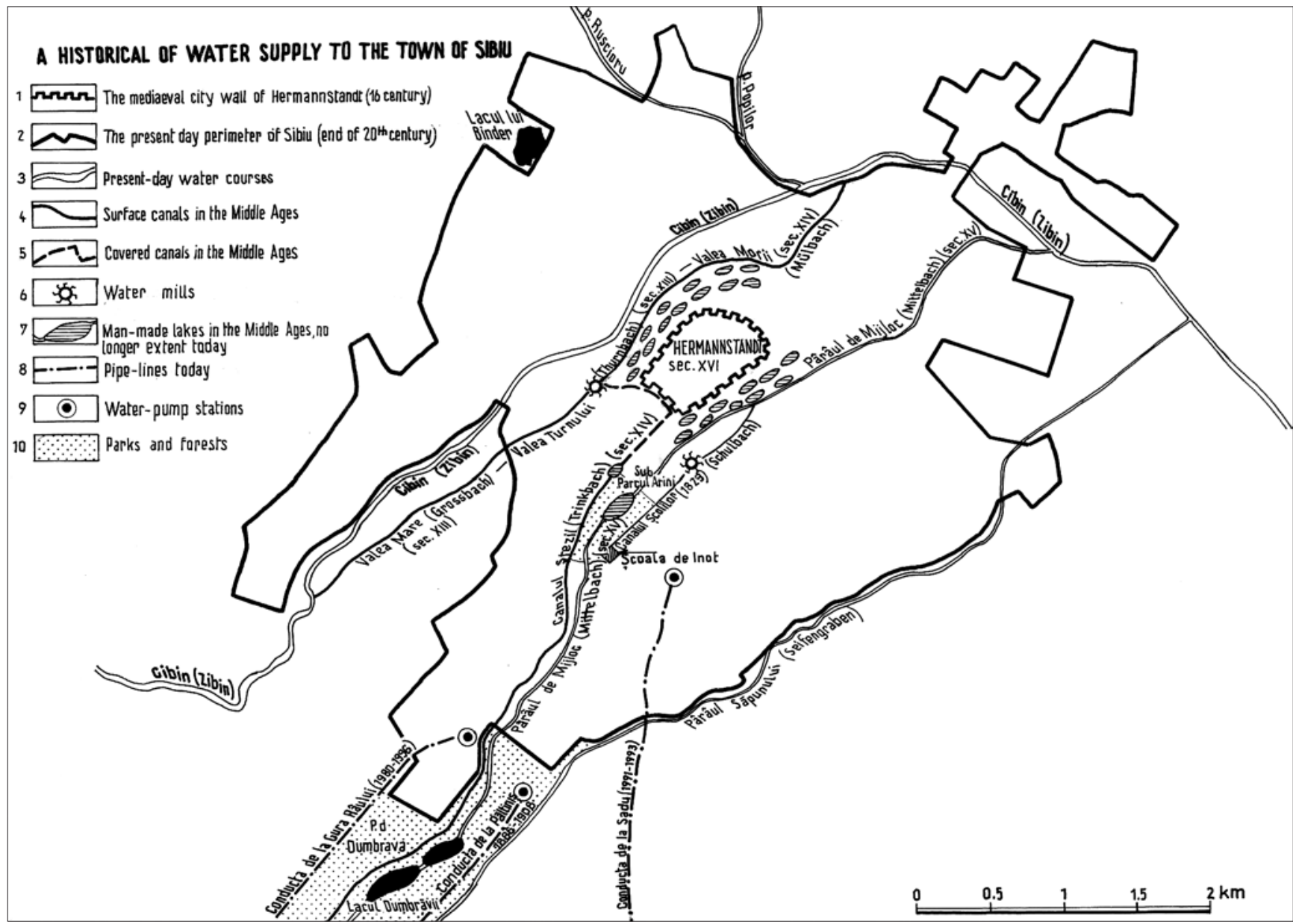

Figure 2. Water supply in Sibiu

The new system remained adequate until well after the Second World War when an intake at Gura Râului was opened in 1966, followed by a pumping station in 1975 and a major water storage of $15.5 \mathrm{mln}$.cu.m in 1980 . This facility now accounts for the bulk of the city's supply. However there is also a small amount delivered from a fourth supply provided in 1991 by extending Cisnadie's system of 1933 based on Sadu II power station tailrace just below the lake. The total supply of water in 2004 was $32.95 \mathrm{mln}$.cu.m

However while Sibiu primarily served its own privileged community a case could be argued to suggest a colonial relationship between the Saxon towns and the Romanian hinterland. The urban guilds were closed to Romanians and attempts were made to prevent competition from the villages. In 1724 the town's wheelwrights were able to enforce their monopoly through 'inspections' at Răşinari. However such controls were not sustained and did not prevent the village from becoming a great handicraft centre in its own right. Meanwhile the Saxons themselves moved out into the rural area for Gura Râului had a wool spinning industry linked with cloth production in Sibiu (Giurcăneanu 1988, p.256) and in 1847 Johann Bedeus started a cotton spinning business in Orlat with 25 workers. There was also a paper industry at Orlat during 1821-59. Maybe German entrepreneurs wanted cheaper labour and easier access to raw material, clean water and water power - or did they wish to innovate away from the gaze of the business community? Saxons (and Italians) were working in the forests from the early nineteenth century. And the growth of outdoor recreation in the area also had a Saxon inspiration. Traditional routes used by pastoralists to reach the peneplains became useful for hikers; for example the trail from Crinț, above Săliște, to Duşi, Strâmba and the Cindrel summit, which is now endowed with a chain of 'cabana' accommodations expanding from Cabana Soarelui $(1,200 m)$ southwards; also from Răşinari to Râu Sadului, Tomnatic and Vf.Galbena (on the summit of the Lotru Mountains) to Voineasa.

Meanwhile the wealthy ruling class of Sibiu was able to found a new mountain climate station (Hohe Rinne now Păltiniş) started during in $1892-4$ by the Saxon tourist society Siebenbürgische Karpaten Verein. The resort occupied a sheltered position in the mountains where the early buildings included the initial Tourist House (Casa Turiştilor) in 1894, followed by Casa Medicilor (1895) and Sala Monaco (1898). It became a centre for rambles through the coniferous forests to Cheile Cibinului and also the mountain summits of Cindrel $(2,244 \mathrm{~m})$ and Vf.Batrâna $(1,911 \mathrm{~m})$. Meanwhile the area was opened up in the 1890 os by the railway which served not only Sibiu (with a branch to Cisnădie) but also touched the Romanian villages at both Sălişte and Tălmaciu. Cultural organisations were also developing (like the choir at Poiana Sibiului formed in 1908). Sibiu was now developing as a service centre for a wider hinterland and after the 1848 revolution Romanians were able establish a commercial presence with their 'Banca Albina' in 1872 and the depository house 'Casa de Păstrare' in 1884; not to 


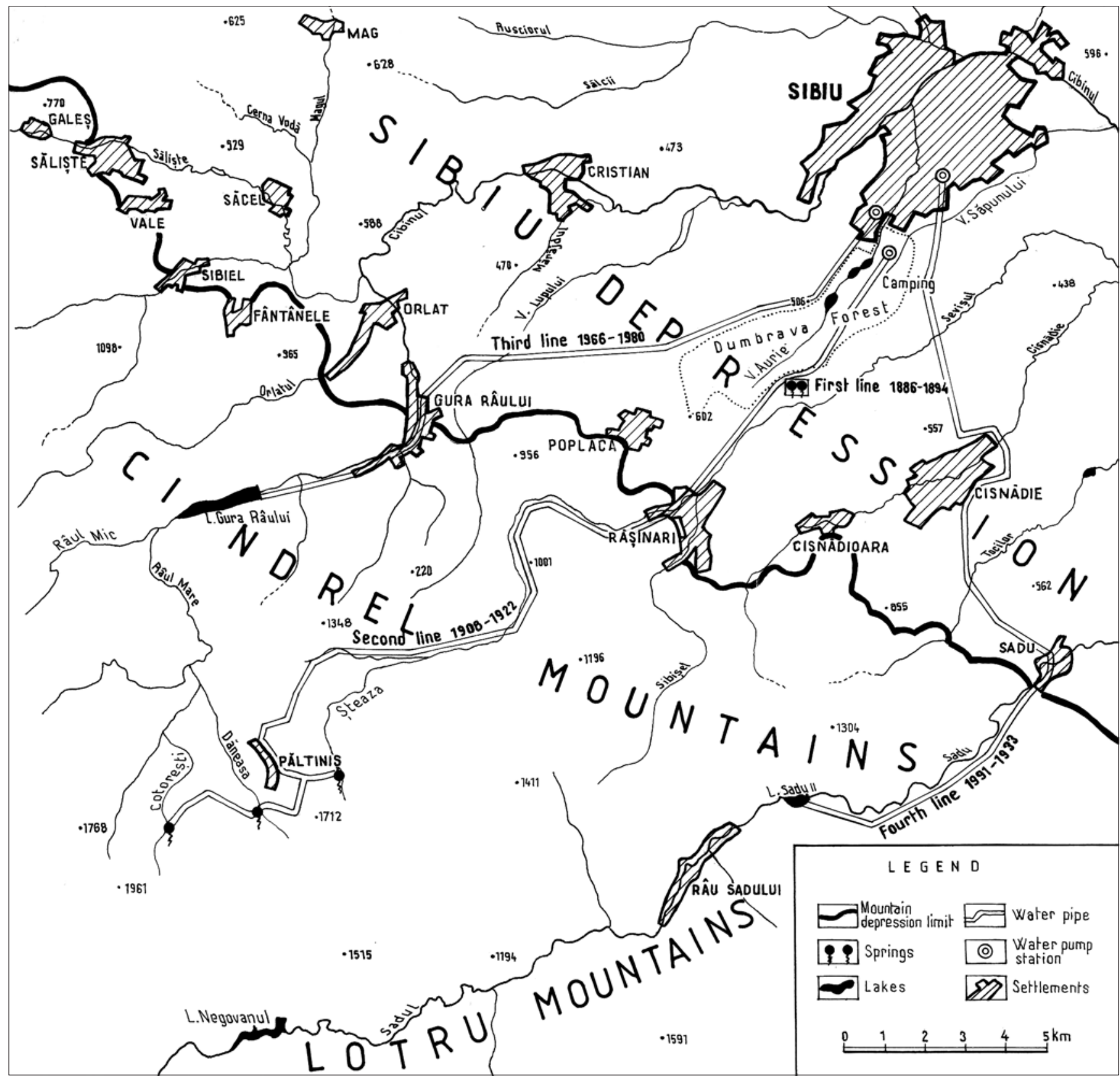

Figure 3. Water pipelines to Sibiu

mention some cultural organisations with imposing purpose-built premises like the Transylvanian Association for Romanian Literature and Romanian People's Culture (ASTRA) which served the wider community throughout the province. The Orthodox Chuch gained status in the town in the 1860 s and a metropolitan seat was established. There was also a representative Transylvanian Diet established in 1848 although it was suppressed following Vienna's 'Ausgleich' (compromise) with the Hungarians in 1867 . However the Romanian population remained a small minority at this time although the proportion increased from 2,089 out of a total of 12,765 in 1850 (16.4\%) and 7,106 out of 29,577 in $1900(24.0 \%)$.

\section{Sadu}

This locality provides an interesting case study. In 1799 the Romanian community was released from a state of servitude under Cisnădie but while the Saxons renounced their right to impose serfom and 'robot', the boundary was drawn in their favour until the twentieth century. They also gained Lăzăturile and the clearing between Valea Cioară and Valea Tocilelor and the Tufari forest in 1800 as a result of the decisions of the Saxon 'Magistrat' in Sibiu. Following the initial award in 1646, Cisnădie also retained exclusive rights to the Sadu river. The Romanians occupied land and were able to build their own fulling mill and cereal mill some distance from the Saxon installations, but rents were payable. This encroachment arose because Cisnădie lacked water power (and indeed a good water supply of any kind). So it was in Sadu where the Saxons built a fulling mill in 1646 (with 'zece pive de bătut dimie' according to Lotreanu 1988, p.14); followed by a brewery (named 'Prund') and an eighteenth century distillery using Romanian cereal (1784). At the beginning of the nineteenth century there are further references to fulling (by the Cisnădie guilds) and corn milling, but most interesting was the spinning and weav- 
ing mill started by Dr.Ioan Piuariu-Molnar von Müllersheim in 1784 which enjoyed a high reputation in Vienna. Indeed in Transylvanian statistics for 1792 it was one of just three 'capitalist' industries in the province. Apparently the family sold out to Saxons from Agnita in 1815 and then the factory was acquired by Thomas Binder of Cisnădie in 1892 who expanded the complex with a brewery in 1912-3 (while there was also 'joager' producing staves for barrels needed by the brewery).

The Sadu saga is also embroidered by an early hydropower project when the Munich engineer Oscar von Miller was engaged by Sibiu businessmen led by Karl Wolff. The station opened in 1896 with two Ganz-built Girard turbines with an installed power of $185 \mathrm{Kw}$ (Pop 1996). A 4,500v line reached Sibiu in 1896 (the first town in Hungary to receive electricity and the first instance in present-day Romania of a town supplied with electricity over an appreciable distance by a medium-tension line). The station was supplemented in 1897 by a wood-burning generator with a similar group added in 1898 for use if the river level was low. When the first hydro unit was uprated in 1905 the total capacity reached almost $1.7 \mathrm{MW}$ with a normal annual output of $3.5 \mathrm{GWh}$, (90\% of which could now be realised at low water thanks to the thermal component). The Girard turbines were changed for Francis turbines of 2x35ohp in 1916. Meanwhile in 1906-7 von Miller went on to build Sadu II, five kilometers above the first station: $0.20 \mathrm{mln}$.cu.m of water was impounded by a $13.5 \mathrm{~m}$ high dam $78 \mathrm{~m}$ long to provide a steady flow along a two-kilometer 'galerie de presiune' to a tower ('castel') from where there was a fall of $48 \mathrm{~m}$ to the power station (Pop 1996, p.26). A further turbine was installed in 1926 when the thermal units were removed and the two unit system continued to operate as a purely hydropower unit with a combined capacity of $1.7 \mathrm{MW}$. The reservoir was refurbished in 1966-9 when a deviation channel was installed to evacuate flood water and ease the problem of silting. A house for technicians became Cabana Valea Sadului after nationalisation while a historic placename at the site ('Puntea Băii') recalls a former forge when Saxon craftsmen worked iron to make farming tools that were taken out by cart over Măgura hill to Cisnădie for finishing for Sibiu market. Thus it can be seen that great ingenuity was displayed in harnessing hydropower technology to supply Sibiu (before a national grid was conceivable) and it provides a further example of the ecological linkage between the town and its hinterland.

\section{Contemporary settlement: The twentieth century}

\section{The rural economy}

This continued largely as before, but the frontier disappeared and Romanian control of local government opened the way for the uninhibited development of cultural and social institutions exemplied by the very substantial 'Caminul Cultural' (Culture House) complex in Răşinari dating to 1929 (Miclea 1985). Giurcăneanu (1988, p.257) claims that the 1918 union of the Romanian lands stimulated agricultural development in the area (through fruit growing) as well as forest exploitation, local industry and tourism. Land reform in
1923 meant that pasture beonging to the Sadu brewery was allocated to the Romanian community and partially used for housing. Along with the village of Râu Sadului they also regained some mountain grazing. We hear about the periodic rebuilding of the pasture stations e.g. Fântânele's Ştefleşti 'stâna' was reconstructed in 1935 by the Poiana Sibiului shepherd Manițiu (Irimie et al. 1985, p.309); while a new 'model' stâna replaced the ruin on Beşineu mountain in 1955: a large construction meeting all the needs of a pastoral life (Ibid, p.316). Rather less benign was the cutting and burning of scrub (Pinus mugho and Juniperus sibirca) on the high mountains. Great fires were reported in 1947 on Canaia (2,040m), Iujbea $(1,800 \mathrm{~m})$ and Niculeşti $(2,036 \mathrm{~m})$, although it was later appreciated that this was not a sustainable practice for enhancing grazing capacity because of erosion (which has also occurred through clearfelling of forests without immediate replanting). Communism brought partial collectivisation, although this did not affect the seasonal movements to the high surfaces that had always had a strong communal dimension. However, most villages avoided collectivisation since the system was logistically problematic in mountainous areas. However Orlat, Săliște and Tălmaciu were exceptions (since they had land suitable for mechanisation on the Soviet 'kolkhoz' model which was the crucial factor). Furthermore, the state farm sector gained a foothold on the high ground through an establishment at Crinț (1,320m) -previously an ordinary 'stâna' site with a modest recreational function - which now provided summer grazing for lowland farms such as Şura Mică, including an intensive livestock breeding complex at Sălişte for cattle and sheep (Iacob 1962). Another livestock unit at Orlat reared bulls for beef cattle farms. Meanwhile the chalets at Crinț were administered by the local office of the state tourist company (ONT) in Sibiu, but in 1975 the accommodation was taken over by the Ministry of Defence and used by the 'Scoala Militară de Ofițeri Activi' in Sibiu while an unsurfaced road access was provided from Sibiel (superseded by a second in 1981, using the headwater of the Sibiel stream that was more suitably graded for vehicles). There was some further cutting of woodland (indeed a small sawmill was erected at Crinț) while fertiliser was applied to improve pasture and stop the invasion of poor grasses. Turning to the towns, the ethnic contrast between town and country was gradually eroded with a Romanian urban majority in 1948 of $61.7 \%$ ( 37,371 out of a 60,602 total) rising to $93.7 \%$ in 1992 (158,863 out 169,610). Initially the Saxons lost ground relatively rather than absolutely, for they were more numerous in $1977(25,403)$ than in $1941(23,579)$ when their overall majority was lost for the first time. Many left after 1989 but despite being reduced to just 5,600 in 1992 they remain influential with their own political party which holds both the mayoral office and a majority on the town council at the present time.

However it seems that under communism the tradition of wintering sheep in the lowlands became restricted to Jina, Poiana Sibiului and Tilişca as all the other settlements restricted their pastoral activities during this period. Much rested on the skills of the shepherds ('ciobani') who not only looked after the sheep owned by private farmers but also the animals belonging to state farms (just as 
they had previously served the feudal landowners). Contacts were also established with Banat cooperatives with regard to wintering grounds, especially in the case of Tilișca - a practice which has been studied in depth by Constantin (2003a, 2003b). The lucrative protected market for wool maintained during the communist period (in addition to the market for cheese and meat) was now a major incentive and the responsibility of supervising large sheep movements called for some mechanisation (e.g. use of four-wheel drive ARO vehicles manufactured in Romania from the 1950s) and even gave rise to a discussion with Ceauşescu over the need for a helicopter! However no community concentrated more on sheep than than the 'Jinari' who successfullly evaded collectivisation. Unlike Sălişte which which had considerable farmland in the depression, local conditions at Jina were unsuitable for mechanisation - a crucial criterion - although a local Roma party activist did launch an abortive iniative in the 1960 s aided by school teachers drafted in from outside. Meanwhile Jina farmers were able to enlarge their flocks - up to 600 or more - with profit margins enhanced because the shepherds were able tobribe cooperative farm officials in the winter grazing areas to accept only token payments. Given the stimulative price for wool set by the state: 'each sheep paid for its entire annual cost with a single kilogram of washed wool' (Stewart 1997, p.70). People visiting Jina would say they were 'going to America' such were the signs of affluence and modernisation in the homes and farms.

\section{Industry}

Large-scale manufacturing continued to be primarily an urban-based activity, though there was a significant rural component based on handicrafts The Saxons' communal cloth mill at Sadu was lost and the premises were redeveloped for housing and a 'cămin cultural', but the brewery survived (along with the local manufacture of barrels): indeed it was nationalised in 1948 and refurbished in 1960, after the production of spirits had ceased in 1958. Small-scale wood processing showed some expansion: Sadu people worked six water-powerd mills or 'joagărele' - some surviving from the late nineteenth century - near Valea Plaiului (some six kilometers from the village) producing planks ('scânduri') with thicknesses of 1.5, 2.5 and 4-5cms, according to market demand and the size of the stems. A family shingle business ('țiglărie') also survived from the late nineteenth century while another started in 1927: both had a reputation for quality with the latter using skilled Hungarian 'țiglari' from Bățani commune (Harghita). Also at the boundary with Tălmaciu (a place called 'Prăhăria'), there was a gunpowder mill. Elsewhere Orlat became a significant centre for sawmilling, while Jina people carted wood to Wallachia (where some continued to settle): they had the advantage of road access to Şugag in the Sebeş valley and from there a new road was driven over the Parâng Mountains to Rânca and Novaci during the inter-war years. Other handicrafts were still much in evidence: Gh.Ghenie (a native of Rod) was a notable joiner and furniture maker during the 1923-44 period: he was based at Sălişte which was centre of such work for the villages in the area (Irimie et al. 1985, p.259). Sălişte also had a furrier ('cojocărit'), while wheelwrights and cart-makers worked in Săliște and Răşinari to serve the local area and even exported.

Communism brought an intensified drive for industry and nationalisation in 1948 was exploited as a mechanism for the consolidation of small industries in the towns since most rural establishments could only continue on a coop erative basis when private entrepreneurs faced very high taxes for the use of water power. All the 'joagărele' closed although a few horse-powered mills survived at Sadu and Gura Râului strictly for local farming needs (Irimie et al. 1985, p.284). However a survey in 1958 revealed a considerable number of joiners and wheelwrights, while Jina, Poiana Sibiului and Râu Sadului had cooperative workshops producing furniture. Textiles were also noted in several plac es including a section of the 'Arta Sibiului' cooperative at Sălişte (with export orders from the US for carpets) and other specialists were concerned with carding, fulling and the production of hats and jackets. However the prime focus was placed on large urban factories which provide a good exemplification of the communist concept of an industrial region. In this case the core consisted of the enterprises is Sibiu and Cisnădie: already a major node for engineering and textiles, along with food and wood processing on the basis of Carpathian resources sucked in with the additional advantage of railway links (Caloianu 1967). The supply of processing water and hydropower has already been mentioned, but there was a further energy source when natural gas arrived from the lowlands to the north (Cetatea de Baltă) in 1937 .

Communist restructuring created the 'Independența' enterprise in Sibiu for engineering (also 'Balanța' and 'Mecanică') and 'Uzinele Textile' in Cisnădie, extending into ready-mades. More specialised outliers developed further afield, including some units in the Mărginimea district: mainly Orlat (with wood processing and the 'Progre sul' cotton textile factory) and Tălmaciu (wood processing/ furniture along with 'Firul Roşu' textile factory) as well as the Sadu brewery. Wood processing was now much more concentrated with Tălmaciu railway station the main site, while the change to lorry transport (first seen at Sadu in 1952-3) resulted in the closure of the two light railway systems in the Sadu valley (Iacob 1991). Linkages arose in various ways e.g. washed wool was sent from Cisnădie to Sibiu and Orlat - also yarn from Cisnădie (and Tălmaciu) to Sibiu - while Sibiu malt went to the Sadu brewery. Finally, half the Sibiu furniture factory's resinous timber was supplied from Orlat and Tălmaciu (also 60\% of the beechwood came from Tălmaciu). Commuter movements made for further integration of the Sibiu complex although the predominant flows by rail and bus (as well as the Răşinari tramway) were from the outlying rural areas to workplac es in the core of the region. While all the villages enjoyed bus services to Sibiu, mainly through the route from Jina, Caloianu (1973) indicated significant differences in the intensity of commuting between agricultural villages (Jina, Poiana Sibiului, Rod and Tilişca) with a low level of commuting and others (Fântânele, Galeş, Săcel, Sibiel and Vale) with a more significant activity and mixed settlements with a substantial level of travel to work (Boița, Gura Râului, Poplaca, Râu Sadului, Sadu and Sălişte) with particularly 
high levels for Orlat and Răşinari. Urban status was extended to Cisnădie in 1965 and Tălmaciu in 1989 (after Tălmaciu had first been declared a suburban settlement in 1968 along with Răşinari - including Poplaca - and other places on the edge of the city).

There was further hydropower development in the Sadu area because another four projects (Sadu III-VI) were envisaged to provide a further $31 \mathrm{MW}$ of capacity. However, due to the high costs in relation to output, only Sadu V was actually implemented (during 1950-5) with 15.5 MW installed in two Pelton groups of $7.75 \mathrm{MW}$ each; with enhanced water storage through an arcuate dam (62m high) impounding L.Negovanu (6.5mln.cu.m) at Gâtul Berbecului (1,154m): an original design by Radu Prişcu. Water was taken to the power power station $6.5 \mathrm{kms}$.downstream through a canal, tunnel and metal tube with a vertical fall of $402 \mathrm{~m}$. With further improvement in water supply, a Francis turbine of $10.5 \mathrm{MW}$ brought the total to $26 \mathrm{MW}$ in 1960 . And when added to the existing power stations the total capacity became virtually $30 \mathrm{MW}$. But although the other components of the 1950 scheme - Sadu III (3.8MW), Sadu IV (4.8MW) and Sadu VI (10.0MW) - were abandoned due to the high investment cost - and the availability of further power through the national grid system - the plan was briefly re-activated in 1974 with a view to building Sadu VI at Rozdeşti and Sadu III at Tălmaciu. However the potential still did not justify the investment (likewise an increase at Sadu I/II to a total of $12 \mathrm{MW}$ ). But there was progress over a plan to develop the Cibin above Pisc (Gura Râului) with a barrage at 6oom to draw on the upper basin of $147 \mathrm{sq} . \mathrm{km}$ basin that was $75 \%$ forested. This was conceived primarily to augment the water supply for Sibiu through a $14 \mathrm{~km}$ pipeline to a treatment station at Dumbrava. In this case hydropower was an incidental interest involving a small (3.5 MW) power station below the dam. The scheme was completed in 1980, while another project for Lunca Craciuneasa (where the valley widens upstream of Cheile Cibinului) was considered unviable. Since 1989 the rising price of electricity has rekindled interest in small hydropower stations: an investment of $€ 10 \mathrm{mln}$ can produce power worth $€ 2 \mathrm{mln} / \mathrm{yr}$. A new power station at Gura Râului opened in 2008, while two more on the Râul Mare are planned, plus two on the Cibin at Cristian and possibly three in the Şteza valley at Răsinari. The capacity at Sadu is now $27.4 \mathrm{MW}$ at Sadu V and a total of 4.44 at the two older stations; while the micro stations on the Cibin total 3.70MW.

\section{Rural services}

In the villages territorial expansion has given way to qualitative improvements in services as Possa \& Mihalik (1966) indicate for Poiana Sibiului. In 1923 the villagers decided to build dykes along the principal valley to remove the flood risk at Piața din Vadu. Electrification began during the interwar years and start was made to modernise the water supply by building a small reservoir and pipeline to supply fountains ('cişmele publice') at several points in the village. These were communal projects of the 1920 s supported by local contributions of labour and money, reflecting the tradition of joint action and stewardship inherent in the old concept of the 'obst' as a traditional peasant community. Under communism local industry expanded through a dairy while cooperativisation of agriculture gave rise to expansion of the livestock sector. Health facilities were improved with a local dispensary, a maternity unit and dentist's surgery, while the school was enlarged by new classrooms, a laboratory and a nursery. Electrification was completed and the first television arrived in 1963, while the building of new houses also took off at this time with about 20 houses per annum reported in the 1960 s. The tradition of the Sunday market continued at Piaţa Târgului (otherwise known at Piața de pe Dealu) before transferring to Piața de Vadu: vegetables were brought in from lowland areas as were supplies of wheat and maize for which there were milling facilities locally. Local animal products were exchanged in the autumn for wine and grapes. A 'camin cultural' opened in Piața de Vadu in 1958 providing filmshows as well as library and sports facilities. A local museum was an important subsequent achievement, while the choir was revived in 1949 and competed widely in the region and further afield. Staule - an old oakwood on the Jina road - was developed for open-air entertainment on the occasion of 'Maial' (1 May) and other festivals while 25,000 trees were planted on Ghilghiu to make a woodland park.

\section{Transition strategies: The pastoral economy}

Despite the restitution of agricultural land (in 1991) in areas that were cooperativised under communism, interest in agriculture seems to be declining especially where arable farming is concerned: maize and fodder crops remain prominent while there is less emphasis on other cereals (wheat and barley) and potatoes. Indeed some arable land has been abandoned; very noticeably around Răşinari; also at Sălişte as well as Fântânele, Sibiel and Vale where fruit trees (apples, pears, plums, cherries and nuts) are particularly prominent, given the smooth hilltops on the edge of the depression, and a strong shepherding tradition is absent. Damage from wild boar means that potato fields must be fenced especially in settlements near the forest. Jina people also grow onions, tomatoes and cabbages in their 'gradini'. However, most rural settlements retain a pastoral interest: especially villages on the Gornovița peneplain and most notably Jina with an extensive territory extending to the alpine zone (whereas the neighbouring village of Poiana Sibiului is much more restricted). Indeed 'Jinari' and 'Poienari' practiced transhumance to winter grazings in $\mathrm{Ba}$ nat, Dobrogea and Oltenia - as well as movements to the higher Râul Şes and Borascu surfaces in summer - into the new millennium when EU hygiene and animal welfare regulations (on top of local difficulties on the transit routes) brought long-distance movements to an end. They had previously adjusted to the 1989 revolution when state contracts for wool ceased and free trade brought lower profits that were, however, broadly acceptable given the adequately rewarding prices for cheese and meat (stimulated in the latter case by the great home demand for lamb at Easter as well as a resumption of the meat shipments to Arab countries developed under communism). But tougher negotiating with private landowners created complications on the transhumance routes (especially the slow spring return with new-born lambs). Flocks were reduced substantial- 


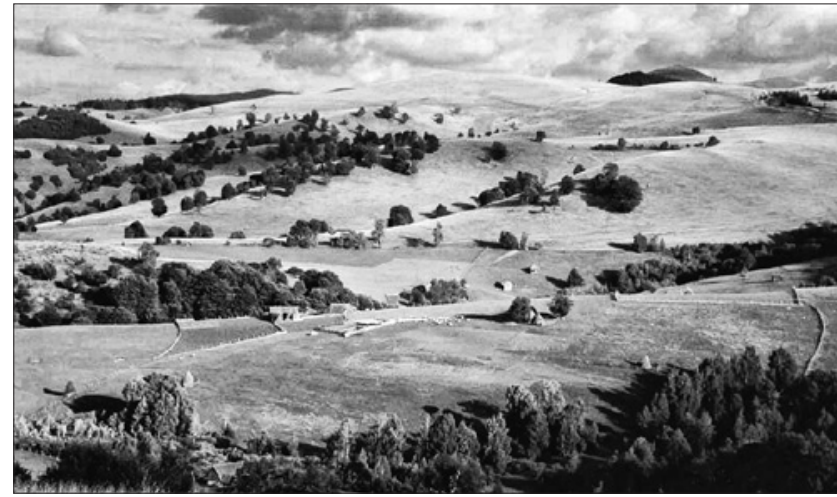

Plate 6. The high grazings of Hotarul de Sus on the Gornovița peneplain c.100om above Jina (S.Shirasaka)

ly while alternative business arose through embargo trade with Serbia (during the period of civil war in the former Yugoslavia); also wool deals with Turkish lorry drivers; and speculation in the early days of the Caritas pyramid investment scandal that generated profits invested in garages on the main roads. Using their family networks the Jinars "expanded their activities from the mountains into the plains, using their home base as a sort of bank, secure from the depradations of the state and outsiders" (Stewart 1997, p.72). Since 1989 some 200 families have moved into lowland villages around Sibiu acquiring houses from departing Saxons (often taking their jobs as well).

However Jina remained a most important centre for the transhumance of sheep ('mioara românească') according to recent research by Shirasaka (2006; 2007). Local pastures provide grazing for use at the lower levels (Hotarul de Jos) for a short time in the first half of May and the first half of October between the return from wintering in the lowlands (October to April) and the transfer to 'Hotarul de Sus' (the Gornovița peneplain at 950-1,10om) during the period from mid-May/mid-June until mid/late September (Plate 6). These summer grounds also extend upwards to comprise alpine pastures on the highest part of the commune on the Borascu (2,000-2,200m) and Râul Şes $(1,800 m)$ peneplains (Plate 7) already referred to. Sheep are still entrusted by owners to 'ciobăni' (many from Moldavia, including former mine workers), each of whom look after 200/300 sheep with assistance for milking ( 150 sheep can be milked

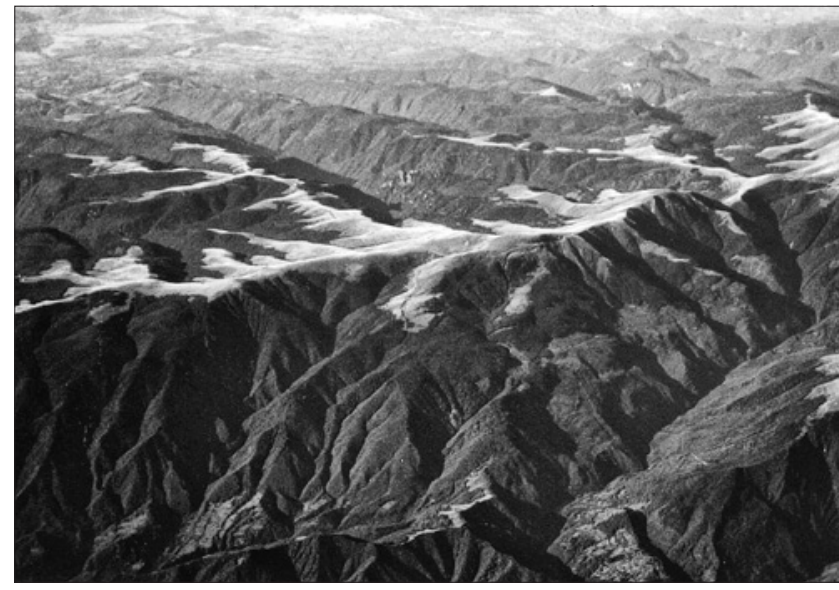

Plate 7. The Râul Şes peneplain at $1800 \mathrm{~m}$ (K.Urushibara-Yoshino) by one person). There is still a serious threat posed by wild animals which account for two to four percent of the total sheep stock each year. Long-wave transhumance continued for a time on a simplified basis using routes southeastwards to Bărăgan, northern Dobrogea and the Danube Delta, or westwards along the Mureş valley to the plains between Arad and Oradea. With individual owners keeping 30-150 sheep (generally Țurcană), combinations of four to seven families could generate flocks of some 600 divided into male sheep (changed usually every three years with animals bred by the owner - or bought at spring/autumn markets), milking females and young females. With lambing in February/March more shepherds were needed for the transfer from winter to summer grazings with the impor tant Easter market for lambs imposing great pressure to get the flocks back home in time.

The use of modern forms of transport became increasingly necessary given the hazards of driving flocks along the highways and increased costs caused some villages to give up long-distance transhumance altogether after 1989. The business then came up against EU rules concerning both the transhumance operations (an animal welfare mat ter) and the cheese sales (at Sibiu market and large stores in Bucharest) became more strictly controlled in the interest of hygiene. Even milking at the 'stâna' has been modernised with the use of vessels that can be thoroughly cleaned, not to mention other regulations relating to the technology of food production. There was confusion in 2007 with Bucharest authorities appeared to forbid transhumance despite EU encouragement of traditional methods of sheep rearing through subsidies of $€ 7 /$ sheep in less-favoured ar eas. The EU accepts travel on foot 'pe picioare' but transit routes must be authorised in advance by the veterinary authorities in all the counties concerned. Lorry transport which has been used for a time in Romania - now requires health checks every nine hours; while for long journies lasting more than two days animals must be rested on a farm authorised for the purpose. A new strategy has therefore evolved to limit pressure on local grazings while avoid ing long journies for the animals: this involves year-round sheep grazing in Banat, where the softer climate makes for a better output of wool and cheese; also with minimal threats from wild animals and scope for mechanised production of silage. But this means that some farmers have left Jina and return home only at Christmas (retaining their 'ciobăni' all-year). And it requires assured access to land through purchase when the going rate $-3.0 \mathrm{mln}$ lei/ha in 2004 - equalled the monthly wage of a shepherd, though some meadow land ('fâneață') may be rented.

Meanwhile Jina's local meadow land at Hotarul de Sus provides hay for cattle - 2.5-3.ot (1.oha) per cow for the winter: stored in buildings or left as 'claie' in the fields. In some places hay is needed for sheep: one hectare for every seven animals. There is however a statistical problem over Jina regarding the number of sheep currently being kept. According to Shirasaka (2006, p.87) 33,000 sheep were recorded by the authorities before 1989 while the true number was thought to be 300,000 ! Present numbers are difficult to establish but officially Jina had 37,000 sheep in 2002, increasing from 17,250 during 1997-9 and Poiana Sibiului had 35,100 
Table 2. Livestock Units in relation to population and agricultural land 1997-2002

\begin{tabular}{|c|c|c|c|c|c|c|}
\hline & A & B & C & $\mathrm{D}$ & $E$ & $\mathrm{~F}$ \\
\hline \multicolumn{7}{|l|}{ Mărginimea Sibiului } \\
\hline Gura Râului & 2488.1 & $744-40.1$ & $629-43.8$ & 687.1 & 1400.6 & 1.78 \\
\hline Orlat & 1037.8 & $621-52.1$ & $525-50.4$ & 317.3 & 838.7 & 1.24 \\
\hline Jina & 4223.8 & $5180-78.1$ & $2422-75.7$ & 1037.0 & 2132.3 & 1.98 \\
\hline Poiana Sibiului & 3496.9 & $4914-99.0$ & $2660-97.5$ & 1261.9 & 296.5 & 11.79 \\
\hline Jina / P.Sibiului & 7720.7 & $10094-94.3$ & $5082-85.7$ & 1124.0 & 2428.8 & 3.18 \\
\hline Poplaca & 575.1 & $99-14.8$ & $62-13.8$ & 323.3 & 564.1 & 1.02 \\
\hline Răşinari & 4164.6 & $3827-85.5$ & $2961-78.4$ & 753.2 & 1329.6 & 3.13 \\
\hline Râu Sadului & 1240.7 & $1086-82.9$ & $918-85.5$ & 1950.8 & 342.5 & 3.62 \\
\hline Sadu & 1673.3 & $959-56.6$ & $781-45.6$ & 676.9 & 982.3 & 1.70 \\
\hline Sălişte & 2602.1 & $1228-51.8$ & $1081-47.6$ & 449.0 & 6241.6 & 0.42 \\
\hline Tălmaciu & 2488.1 & $1694-58.6$ & $1232-60.8$ & 281.6 & 2628.6 & 0.95 \\
\hline Tilişca & 2820.9 & $2640-87.9$ & $2138-87.7$ & 1697.3 & 913.7 & 3.09 \\
\hline \multicolumn{7}{|c|}{ Adjacent Urban Areas } \\
\hline Cisnădie & 1213.8 & $436-30.9$ & $130-13.5$ & 77.6 & 2932.7 & 0.41 \\
\hline Miercurea Sibiului & 2893.0 & $1191-33.2$ & 804-33.4 & 712.0 & 8738.5 & 0.33 \\
\hline
\end{tabular}

A Livestock Units (cow = 0.84; pig 0.20; sheep/goat 0.14; poultry 0.04) average for 1997-2002; B Ditto for sheep and goats alone: highest figure during 1997-2002 with percentage of the total units; C Ditto: lowest figure for sheep and goats; D livestock units per 1000 population 2002; E Land units where 1.0ha of arable = 1.0; vineyards 8.0; orchards/vegetable gardens 2.0; hayfields 0.3 and grazing 0.1; F Livestock units per land unit

in 2002, increasing from about 19,000 during 1997-9. Relatively high numbers also apply at Răşinari (21,700 in 2002) and Tilişca (18,335 in 2002) while all the other communes have below 10,000. In other villages such as Galeş, Rod, Râu Sadului and Tălmăcel there are fewer animals since the winter transfers have been given up and the livestock (sheep and cattle) are limited to what the local hay meadows can provide (whereas the 'Jinari' and 'Poienari' used to require hay only for cattle). On the other hand these villages are situated in the depressions where there is more arable land (albeit fragmented into small units).

To highlight the variations in stocking levels animal numbers have been converted into an overall total by a series of conversions (used by researchers at the Geography Institute in Bucharest in the 1970s) based on meat yield (Table 2). When total livestock units are related to population (Column D) Jina, Poiana Sibiului, Râu Sadului and Tilişca have the highest values with more than one unit per capita. But when stocking is related to local land resources (Column F) Jina's position weakens very greatly (since this commune's relatively extensive land resources are relatively limited in potential due to the high altitude) while Poiana Sibiului - with very little land of its own - becomes the outstanding case. While Jina scores only 1.98 animals units per land unit - admittedly much higher that most other communes, including urban/suburban areas (as well as Gura Râului, Orlat and Sadu) - it is well behind Tilişca with 3.09, Răşinari with 3.13, Râu Sadului with 3.62 and Poiana Sibiului with 11.79! Of course it cannot be assumed that Poiana uses only it's own land when Jina commune is so much larger; while much of Jina's land can only be fully exploited in conjunction with wintering grounds elsewhere. Combining the two communes produces a reasonable average figure of 3.18; albeit one that is depressed by the hiving-off of flocks to areas of low ground adjacent to our study area where the demise of local cooperatives has created opportunities. Also, as already noted, some 'Jinari' have purchased land in the western plains of Romania (Arad, Bihor and Timiş counties) where the animals can remain all the year round. And these practices seem to have become more common with the complications of EU hygiene and animal welfare regulations

However pastoralism remains important through cheese and wool sales as well as the disposal of animals for the meat market which peaks during the Easter festival (Plate 8). Public interest in the mountain economy is being promoted by the Mountainology Instiute at Cristian near Sibiu with the cooperation of the 'Mărginimea' organisation (the county association of sheep and goat rearers) who have placed a genuine mountain 'stâna' on exhibition (Plate 9). But intensive livestock rearing in some parts of the district has given rise to localised environmental problems which form part of the wider issue of geographical risk in the Carpathians (Florea 1996; Velcea 1998). Degradation, especially on the Gornovița peneplain, is evident in Jina and Poiana Sibiului where overgrazing and trampling accelerates ero-

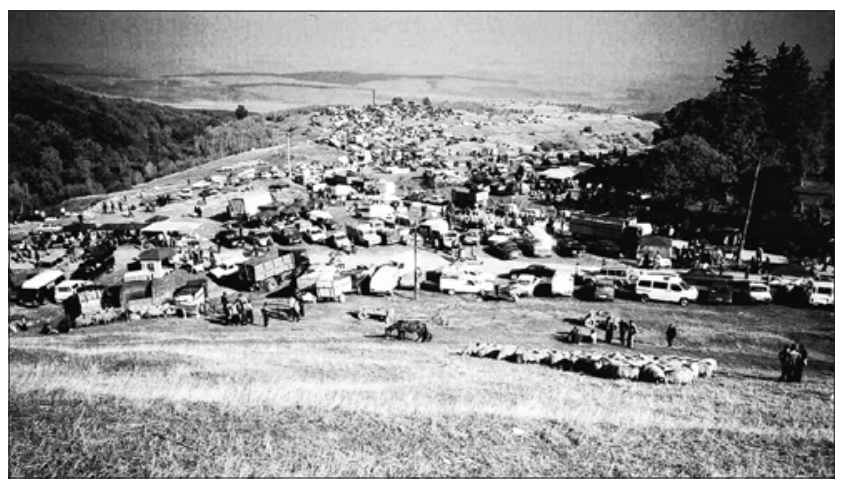

Plate 8. The sheep market at Poiana Sibiului 2004 (S.Shirasaka) 


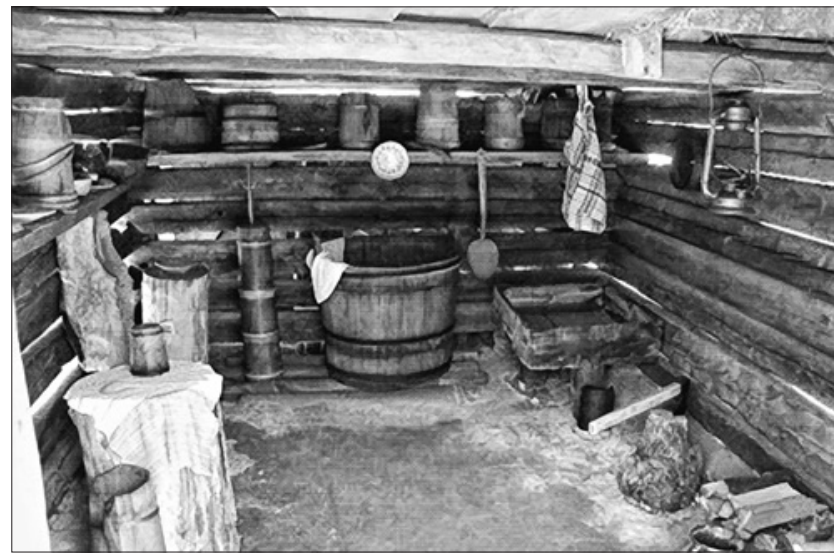

Plate 9. Stâna interior (M.Cojocariu-Costea)

sion e.g. around waterholes in cattle-grazing areas (Urushibara-Yoshino \& Mori 2007). Truck tracks, arising from the random driving of vehicles across open country, are very noticeable in some areas; while the pollution of streams through washing wool (typically by Roma who often make direct use of the Cibin during the summer season) is evident in a high ammonia content (Plate 10). These problems are exacerbated by overdependence on sheep-rearing (re flecting the lack of alternative employments) as well as the tradition of communal ownership of pastures, along with low environmental awareness and administrative 'capacity' to enforce legislation. It would be beneficial if wool washing could be undertaken by producer associations with concentration on a few places with proper arrangements for handling the polluted water. But for improved grassland care, sheep numbers clearly need reduction in places where overgrazing is removing the vegetation cover and soil is being washed away to expose the crystalline schist so that recovery of the pasture becomes impossible. But these are merely local expressions of a much wider issue of changing land use in areas of traditional farming in Transylvania (Cowell 2006).

\section{Diversification: Rural tourism}

The agro-pastoral emphasis remains very strong. Pastoralism is most prominent at Galeş, Jina, Poiana Sibiului, Râu Sadului, Rod, Tălmăcel and Tilişca; with fruit growing most evident at Fântânele, Sibiel and Vale. As regards other branches of the local economy, there is logging which includes small-scale sawmilling through family-owned mills 'joagăre', with substantial areas of forest now restituted and administered by a private district ('ocol silvic') organisation. A 'forest/pastoral' settlement grouping would include Galeş, Râu Sadului, Rod, Tălmăcel and Tilişca - as well as Sadu which has an additional interest in hydropower. Meanwhile, rural tourism has made rapid progress, having been constrained under communism by restrictions on foreign visitor use of private accommodation imposed nationally in the early 1970s, although Sibiel (renowned for its collection of icons on glass) received some official encouragement for a time. Today several villages can be regarded as 'sate de vacanță' as a result of farm-based boarding houses ('pensiune') with up to 10 rooms as well as the growth of holiday homes (e.g. Valea Sadului and Gâțul Berbecului) plus improved catering and transport services in plac-

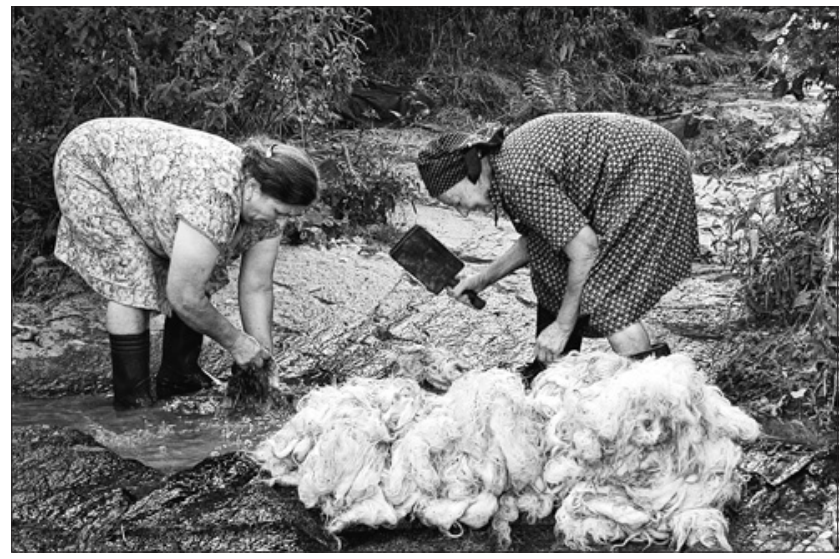

Plate 10. Washing wool in the Cibin river (K.Mori)

es such as Gura Râului, Răşinari. Râu Sadului and Sadu coordinated by the national non-governmental organisation ANTREC. Sălişte (along with Fântânele and Sibiel) probably has the most accommodation, although it is not a specialised holiday settlement, despite its many attractions including the Foltea Hermitage and the wooden sculptures of Poiana Soarelui. There is also considerable capacity at Răşinari and Tălmăcel. Statistics for the district as a whole suggest a fluctuation in the total number of units of accommodation of around 100-120 during 1997-2004.

There is an element of foreign encouragement since the district became involved in 'Opération Villages Roumains': a project launched in Western Europe in the 1980s to oppose Ceauşescu's draconian rural planning ('sistematizare') that threatened to eliminate thousands of 'non-viable' settlements. Although the revolution occurred before this programme could gain momentum across the country, the foreign initiative was maintained for a time in the context of rural diversification and Tilişca entered a partnership with Aubais (France) leading to 'Asociația TilişcaAubais' in 1992 for the promotion of rural tourism, festivals and exchange holidays for children. Along with an increasing number of new houses as permanent residences (with gardens and services) new village quarters have emerged over the last decade as a form of 'rurbanizare' e.g. Tocile at Sadu (Cojocariu-Costea 2002). In addition to the mountain scenery and traditional aspects of rural activity, the tourism potential is enhanced by local folklore festivals which date back to 1858 at Gura Râului (with 'Colindatul Feciorilor' and 'Ceata Junilor'). Another example is 'Udatul Ionilor' at Tălmăcel while 'Sus pe Muntele din Jina' started in 1971 with an emphasis on traditional costume and musicians ('fluieraşi'), as is also the case at Sadu. There is also a 'Teatru folcloric' at Sălişte and an 'ansambluri folclorice' at Răşinari. Poiana Sibiului retains a tradition in leatherwork, while woollen cloth (including traditional textiles) is produced at Orlat and wood/textile handicrafts exist at Răşinari. Museums and collections with a broad rural appeal exist at Boița, Gura Râului (from 1969) and Poiana Sibiului (where links are retained with 'Ungureni' villages in Gorj and Vâlcea by local teacher Ioan Geor gescu); also Răşinari (from 1952) at the the historic 'Bishops' House' once used by the clerics until they moved to Sibiu in 1795 (Plates 11-12). There is another museum at Sălişte (1978) - although it is actually located at Rod where the old 


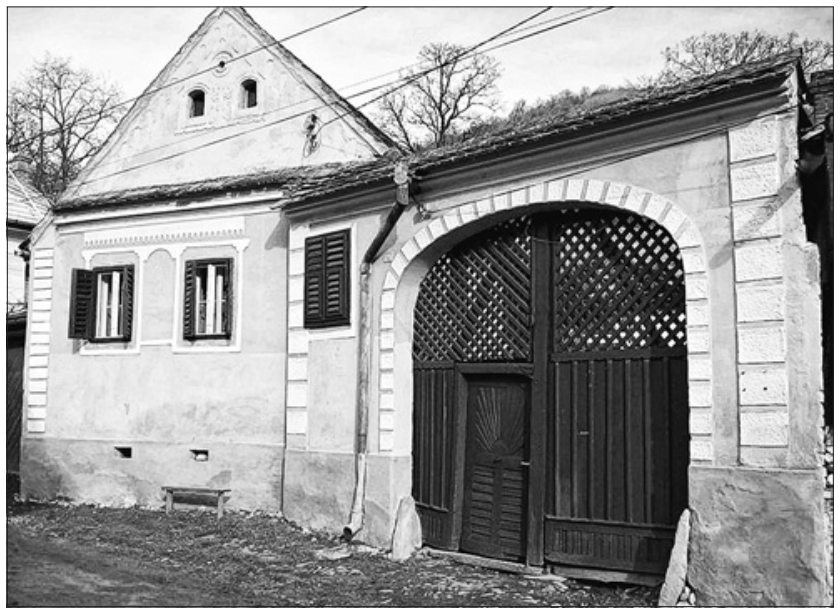

Plate 11. Traditional house at Galeş (M.Cojocariu-Costea)

town hall became available - while there are others concentrating on traditional costume at Galeş and religious matters at Sălişte's 'Muzeul Protopopiatului' - complementing 'Muzeul Personalităților Săliştene' in the same town - and Sadu's electricity museum has turbines dating from 1902 that still operate. There is a remarkable 'Zosim Oancea' collection of 700 icons on glass at Sibiel, started in 1769, not to mention many historic churches among which the oldest are the wooden churches (with painting) at Sălişte (1674, by the Cândeşti Brothers), Poiana Sibiului: a wooden church with painting (1771) that was superseded in 1886; and Tălmăcel which is also in wood (1776). Other Orthodox churches from the eighteenth century exist at Galeş, Jina, Orlat, Răşinari, Sadu and Sibiel while Jina also has the impressive 'Archangels' church' of 1939: a veritable 'cathedral of the mountains' in Byzantine style (Plate 13).

Reference should also be made to the attractions of villages as a whole with traditional housing (Plate 14). Winding streets with particular variety are to be found at Poiana Sibiului where streets in the narrow valleys ('străzile de vale') like Valea Radei show houses crammed into a confined space and facing each other across a narrow street while closed courtyards and gardens are forced on to the slopes: indeed in places only a single row of houses is possible and

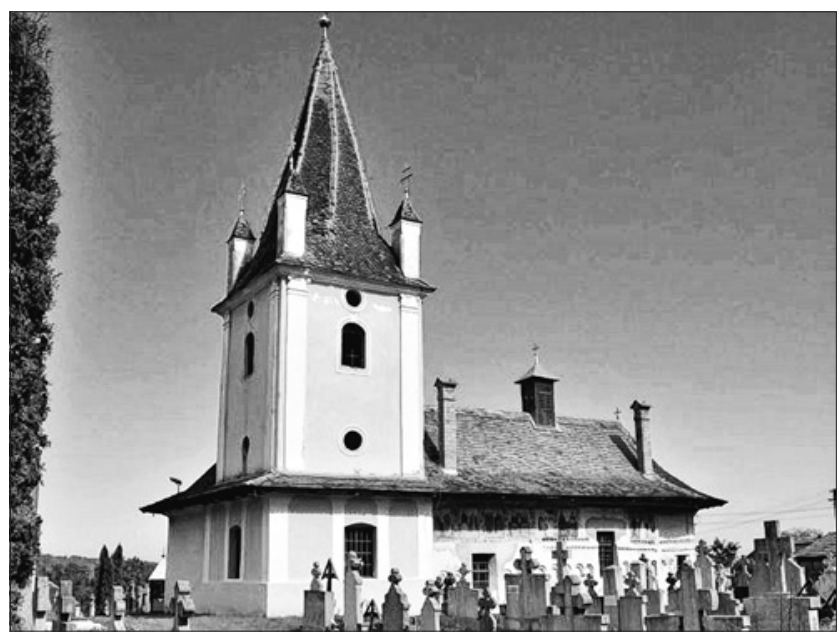

Plate 13. The Orthodox church of Sf.Ioan Botezatorul at Sălişte, built in 1742 with the tower and the painting dating to the second decade of the nineteenth century (M.Cojocariu-Costea)

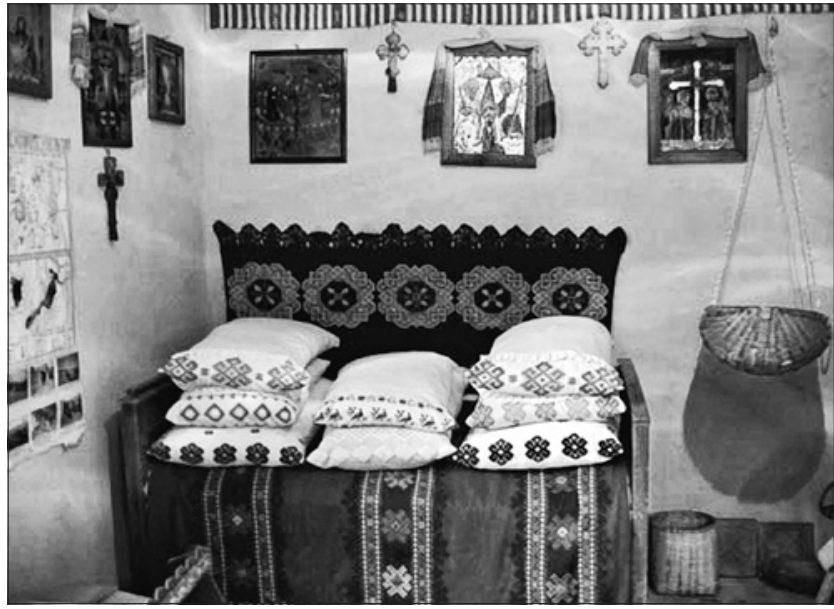

Plate 12. Traditional room in a house at Fântânele (M.Cojocariu-Costea)

gardens disappear altogether. By contrast the streets on the hilltops ('străzile de culme') have to cope with downward slopes: hence the courtyards slope away on each side of the ridge; while the streets on the hillslopes ('străzile de coastă') have two rows of the houses differentiated by their ascending and descending courtyards and gardens; although on steeply sloping ground only a single row of houses is possible, as at Handorul de Jos/Sus where this phenomenon is repeated two or three times on the same slope. The village is thus a true authentic reservation of folk architecture (Irimie et al. 1985, p.377) with the oldest houses dating back to the late eighteenth century. There is also a gastronomic aspect to the tourist profile through local dishes such as the soup 'ciorba de perişoare'; also the flora and fauna e.g. Iezerele Ciudulului nature reserve which can be accessed from Gura Râului. A ski slope is being prepared at Jina, while winter sports are envisaged in V.Ştezii with government and local funding The area is also convenient for 'transit tourism' given the west-east route through southern Transylvania (Arad-DevaSibiu-Braşov) and the north-south route Cluj-Mediaş-SibiuRâmnicu Vâlcea using the Olt valley.

Further reference should also be made to Păltiniş which is actually regarded administratively as part of Sibiu although it lies territorially in the area of Mărginimea Sibiu-

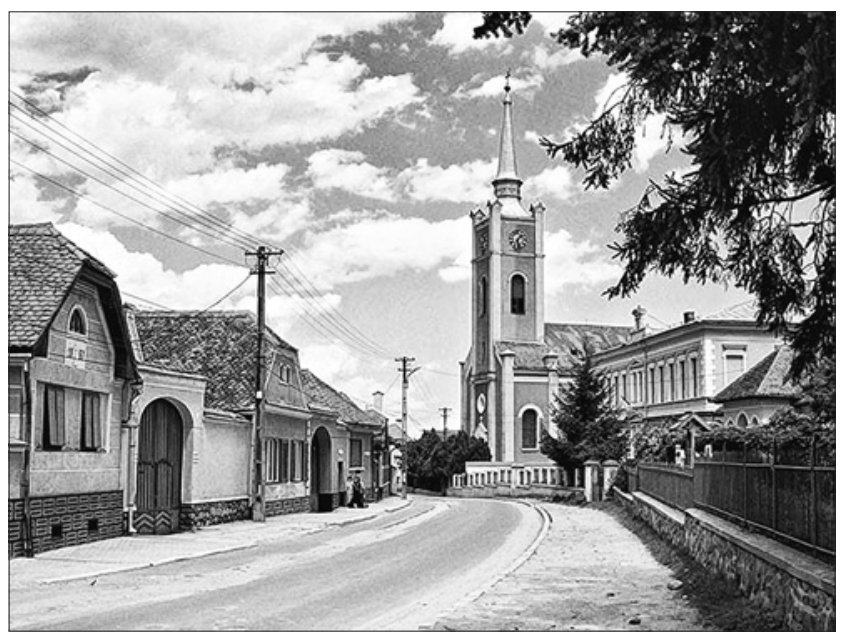

Plate 14. The main street in the village of Gura Râului including the 'Cuvioasa Paraschiva' Orthodox church ('Biserica Mare') of the eighteenth/nineteenth centuries (M.Cojocariu-Costea) 
lui as a part of Răşinari commune. It remains greatly appreciated as a health resort in view of its ozonised air and an atmosphere 'puternic ionizată' that attracted the philosopher Constantin Noica (1907-87) as one of its most notable residents. The accommodation stock of four hotels and some 24 villas and chalets is supplemented by many second homes including a substantial recent extension to the built area. There are now 15 units of accommodation (four of them are listed as historic buildings) (Buza 2004). The recuperative properties of the mountain air have also given rise to a long-established institution for seriously disabled children in Boița (Râu Vadului) which attracted unwelcome scrutiny after 1989 as part of the wider problem of caring from orphan children in the light of Ceauşescu's draconian policies to maintain a high birthrate, This institution has now closed and the children have been transferred to a modern centre in Sibiu with permanent medical and social support. Meanwhile enhancement of the tourist economy calls for environmental protection which is focused on the large Cindrel reserve of 9,043ha spread across Jina, Sălişte and Tilişca communes (Category 5) and the smaller lezerele Cindrelului reserve of 1,046ha at Gura Râului (Category 4). The area is generally pollution-free apart from occasional flood hazards, local traffic and some problems over waste management and agricultural chemicals (Anon 2007). Some pollution arises on the Sadu above Tălmaciu; and also on the Cibin, while the environmental programme calls for river purification at Gura Râului and Râu Sadului as well as some riverbank consolidation on the principle rivers (also the Orlat, Poplaca, Sălişte and Tilişca streams plus the Şteaza and Valea Caselor at Răşinari). Dyking and consolidation measures are anticipated during 2007-10 for Poiana Sibiului (V.Vlasinului andV.Rodii) as well as consolidation of slopes; also at Orlat (on the Cibin and Orlat streams), Sălişte and Tilişca as well as the Sadu at Tălmacel.

\section{Village life}

There continues to be significant commuting to the towns outside the district, especially Sibiu. The variations noted by Caloianu in 1973 still apply; involving the most substantial proportion of the active population (over 1,000 commuters in some cases) at Boița, Gura Râului, Poplaca, Râul Sadului, Sadu, Sălişte and Tălmacel; with particularly high levels for Orlat and Răşinari. The more distant villages (Jina, Poiana Sibiului, Râu Sadului and Tilişca) generate relatively few commuters while Prislop may be placed in a category of its own as a poor Roma community employed mainly in handicrafts. Răşinari enjoys a frequent tram service to Sibiu, currently equipped with second-hand vehicles from Geneva, while there are ten buses daily to Orlat and Gura Râului, but only five to Săliște, Rod, Poiana Sibiului and Jina. There are just two buses to Sadu (one of which continues further up the valley to Sadurel) although other connections are possible with a change in Cisnădie. Meanwhile urbanisation has increased through the promotion of further commune centres to urban status: most recently Sălişte within the district (Plate 15) and Miercurea Sibiului which lies just outside (Voicu-Vedea 1998). Given its industrial role under communism it might be supposed

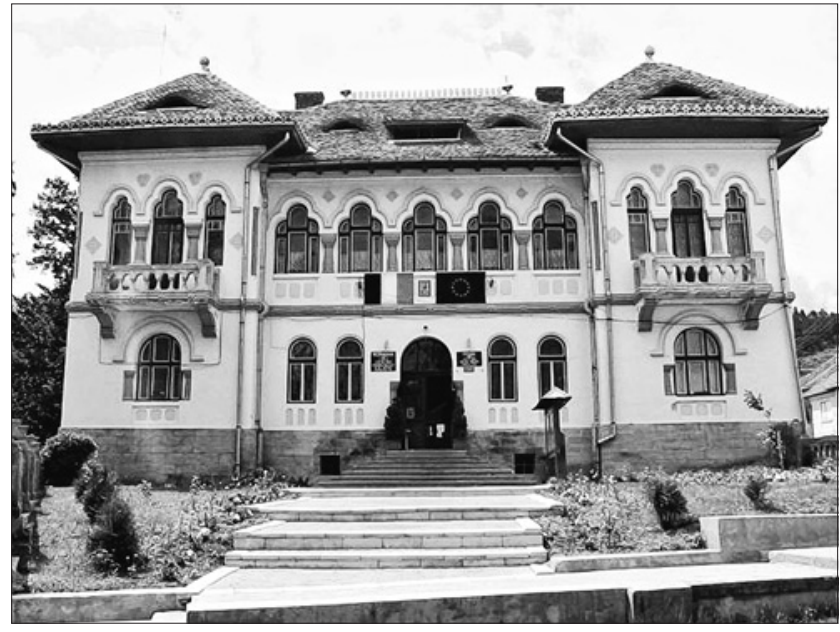

Plate 15. The town hall at Sălişte (M.Cojocariu-Costea)

that Orlat would have a claim (for both Orlat and Sălişte could be credited - along with Tălmaciu - with a mixed economy in contrast to the agro-pastoral bias elsewhere in the district). However, Sălişte had a good situation (historically and contemporarily) as regards its central place functions with regard to administration, education and culture, not to mention food and textile (carpet) industries. It has also seen some of the new business generated by the profits from pastoralism, including a growth in tourism with numerous guest houses and a hotel with 35 rooms. Meanwhile, Orlat - with the tradition of the 'border guards' and an old Romanian school (not to mention its paper industry during 1821-59) - is favoured by its situation in a depression at the contact: it is an obvious collecting centre for wood and wool processing (the latter supported by the hayfields of the Cindrel as well as imported fodder) with workshops that expanded into medium enterprises under communism. It is also has a bakery and produces building materials by exploiting the river beds and valley slopes, But industrial potential is limited by an inadequate water supply from the local stream (while there is no space for a reservoir linked with the Cibin/Sălişte system). So it has no prospects of urban status especially in view of the superior central place status of Sălişte.

The settlements are developing under their new democratic councils with leaders often chosen for their efficiency and integrity rather than party affiliation. All the major parties are represented among present mayors: PC (Conservative Party) at Jina and Poiana Sibiului; DP-L (Democat-Liberals) at Gura Râului, Orlat and Sadu; PSD (Social Democrats) at Tălmaciu and Tilişca; and PNL (National Liberals) at Poplaca and Sălişte. New housing is appearing in the villages but the principal transformations can be seen in the improvements in infrastructure often linked with European programmes. Much progress can be seen in the towns and main villages e.g. apartment blocks for young families at Tălmaciu along with modernisation of the culture house and provision of a kindergarten. Generally electricity, fixed/mobile telephones and cable TV are avail able. But it is necessary to extend water/sewage networks e.g. from Tălmaciu to Tălmacel but also in the Sălişte/Orlat area where Fântânele, Galeş, Sibiel and Vale are relatively well serviced but lack sewerage: hence the large devel- 
opment programme, extending to Poplaca (which needs a water system also) and Tilişca. There are separate water systems at Gura Râului, Jina, Poiana, Râu Sadului, Răşinari, Sadu and Tilișca (as well as Păltiniş) with overhaul to include a new source at Jina while sewerage is a particular priority at Râu Sadului - and a big improvement is also needed at Răşinari where the system is too restricted. Local primary schools are to be improved with libraries; with rehabilitation at Tilişca to include toilets, improved green space and a sports ground. A general programme is needed for gas through a special scheme for the southwestern part of the district covering Fântânele, Galeş, Gura Râului, Jina, Poiana, Poplaca, Râu Sadului, Sadu, Sălişte, Sibiel, Tilişca and Vale. Răşinari has a gas link with Sibiu but this did not include Prislop until recently. Improvement of communal roads is evdent, especially Str.Hulii from Răşinari to Prislop, assisted by European PHARE funding and the training of 10 Roma for employment on the project. Under a PHARE programme of 2003 improved handling of refuse was organised in Cisnădie with Sadu included. Then another PHARE programme of 2005 launched an integrated scheme for recyclable household refuse for a much larger part of Mărginimea Sibiului: based on Miercurea Sibiului/Sălişte to include Fântânele, Galeş, Jina, Poiana, Sibiel, Tilișca and Vale. The aim is to stop indiscriminate dumping and to introduce composting as well as rubbish transfer in Sălişte and Tilişca.

\section{Population trends}

The long term trends shown in Table 1 point to a population peak in many cases in 1992 but in a few instances in 1966 or 1910 while there are distinctive profiles at Sălişte and Tilişca where out-migration was becoming traditional even during the nineteenth century. However when these varied scenarios are combined the total population of the district (ex- cluding the adjacent urban areas) is remarkably stable with the totals for 1857 and 2002 almost identical - on either side of a peak in 1910 - even if the distribution within the district shows considerable change. Meanwhile the towns (dominated of course by Sibiu) exhibit strong growth apart from the most recent intercensal period 1992-2002 for which a downward trend is the norm due to emigration as well as negative natural growth. The urban/industrial centres still attract the younger people, starting with secondary/higher education: thus at Cisnădie the population aged o-30 is 3.46 times the cohort of 60 and over (2.63 for Miercurea Sibiului and 2.79 for Tălmaciu) yet the town of Sălişte has only 1.79. Conversely while Poiana Sibiului also a has a low figure of 1.75 and Tilisca 1.68 - highlighting the transition to smaller families (some with no children) and overall natural decrease in most villages in the district - Jina scores 3.96. It is also interesting to see that population change during 1992-2002 was greatest in the seven smallest villages (below 1,000 population) with an overall 10.1\% decline from 3,015 to 2,711; while the middle group of five (Boița, Tălmacel, Poplaca, Sadu and Tilişca with a population of 1,000-2,500 each) declined more marginally by $-5.4 \%$ from 8,635 to 8,189 . Finally, the six largest settlements of Gura Râului, Jina, Orlat, Poiana Sibiului, Răşinari, Sălişte declined by just $4.3 \%$ from 22,870 to 21,880 , reflecting some movement from the smaller settlements to the commune centres. Yet two of the largest villages lost $-8.7 \%$; pointing to an element of 'crisis' in the two main transhumance villages of Jina and Poiana Sibiului, while on the other hand, one of smallest villages (Prislop) increased from 840 to 898: a Roma village in Răşinari commune near Sibiu, convenient for commuting with a gas supply recently installed.

Natural decrease is a major element in the picture of decline with Poplaca recording the highest rate during the year $2004(-10.5$, based on local records for births and

Table 3. Population, Employment, Land and Households 2002

\begin{tabular}{|c|c|c|c|c|c|c|c|c|c|c|}
\hline & A & B & C & $\mathrm{D}$ & $E$ & $\mathrm{~F}$ & G & $\mathrm{H}$ & I & J \\
\hline \multicolumn{11}{|c|}{ Mărginimea Sibiului } \\
\hline Gura Râului & 3621 & 1785 & 1328 & 1161 & 167 & 2293 & 10545 & 4.77 & 3882 & 1298 \\
\hline Jina & 4073 & 2009 & 1765 & 1759 & 6 & 2308 & 31556 & 5.45 & 7982 & 1355 \\
\hline Orlat & 3271 & 1719 & 1273 & 1090 & 183 & 1998 & 5902 & 3.97 & 2046 & 970 \\
\hline Poiana Sibiului & 2799 & 1500 & 1491 & 1481 & 10 & 1308 & 2347 & 5.85 & 1447 & 1146 \\
\hline Poplaca & 1779 & 881 & 783 & 739 & 44 & 996 & 3267 & 2.61 & 1289 & 720 \\
\hline Răşinari & 5529 & 2834 & 2166 & 1897 & 269 & 3363 & 12787 & 7.56 & 4035 & 1927 \\
\hline Râu Sadului & 636 & 291 & 206 & 198 & 8 & 430 & 3084 & 1.47 & 1021 & 281 \\
\hline Sadu & 2472 & 1256 & 1002 & 838 & 164 & 609 & 4699 & 4.17 & 2061 & 985 \\
\hline Sălişte & 5795 & 2956 & 1898 & 1719 & 179 & 3897 & 22678 & 11.72 & 12110 & 2990 \\
\hline Tălmaciu & 8337 & 4449 & 3113 & 2767 & 346 & 2637 & 18515 & 9.02 & 8898 & 1190 \\
\hline Tilişca & 1662 & 852 & 680 & 664 & 16 & 982 & 5277 & 3.68 & 3494 & 786 \\
\hline \multicolumn{11}{|c|}{ Urban Areas Adjacent } \\
\hline Cisnădie & 15648 & 8066 & 6941 & 5762 & 1179 & 8707 & 13856 & 23.57 & 4003 & 5777 \\
\hline Miercurea Sibiului & 4063 & 2039 & 1300 & 1140 & 160 & 2763 & 8512 & 7.70 & 9759 & 1643 \\
\hline Sibiu & 154892 & 81768 & 68608 & 63585 & 91307 & 86284 & 12164 & 224.7 & 6611 & 57876 \\
\hline
\end{tabular}

A Total Population; B Female Population; C Active Population; D Employed; E Unemployed; F Inactive Population; G Total Area (ha); H. Built Area (ha); I Agricultural Area (ha); J Households. 
deaths), followed by Răşinari (-4.3), Săliște (-3.7), Tălmaciu (-2.8), Poiana Sibiului (-2.6); Orlat (-1.9), Sadu (-0.4). Tilişca has 0.0 while there are positive values for Râu Sadului $(+4.8)$, Gura Râului (+1.4) and Jina (+1.2). Further data is provided in Table 3 which shows that there is generally a female surplus, with just the five exceptions of Gura Râului, Jina, Poiana Sibiului, Poplaca and Râu Sadului. It is interesting to the see the leading centres of pastoralism included in this list (in Tilişca the balance is almost 50:50) underlining the importance of male employment. When umployment is considered there are four communes where this problem seems to be insignificant: Jina, Poiana Sibiului, Râu Sadului and Tilişca; which may again point to the intensity of local agriculture. Usually the active population is smaller than the inactive component (the young and old combined) but there are exceptions at Poiana Sibiului, Sadu and Tălmaciu. Clearly there is scope for more detailed research on the demographic variations.

Ethnicity is also an interesting theme. Across the wider area extending to the towns on the edge of Mărginimea Sibiului, including Sibiu itself, the Romanian population is now overwhelming although before 1992 Romanians accounted for less than 90\% in Săliste and Tălmaciu - proba- bly due to the presence of minorities living outside the traditional limits of Mărginimea Sibiuliu - and less than $80 \%$ in adjacent urban areas where even simple majorities were not secured in all three cases until 1966 (Table 4). However the collapse of the Saxon population since 1989 means that the Hungarians now the largest minority in the towns while the Roma are most prominent in the rural areas, although their numbers fluctuate according to the way they choose to declare themselves in census returns. The official numbers for Roma reached 52 at Tilișca in 1992 (numbers are usually much smaller) and 138 at Poiana Sibiului in 1977: they were reportedly prominent on the edge of this village in 2003-4 washing and grading wool (while the Romanians concentrated on the production and sale of cheese). Roma have taken over some of the old Saxon houses but they have also built their own illegally 'working at low cost without any high level construction techniques' (Shirasaka 2006, p.58). Generally there are 100-200 Roma in Sălişte but there was only one in 1966: a census year when they chose to be completely invisible in Cisnădie, Poiana Sibiului and Poplaca! Yet while Roma numbers were generally low in 1966 there were 135 in Răşinari: more than in 1930 and 1992! On the other hand while there are generally 100-300 Roma in Răşinari there

Table 4. Ethnicity: Romanians in numbers and percentages of the total; also other ethnic groups and overall percentages

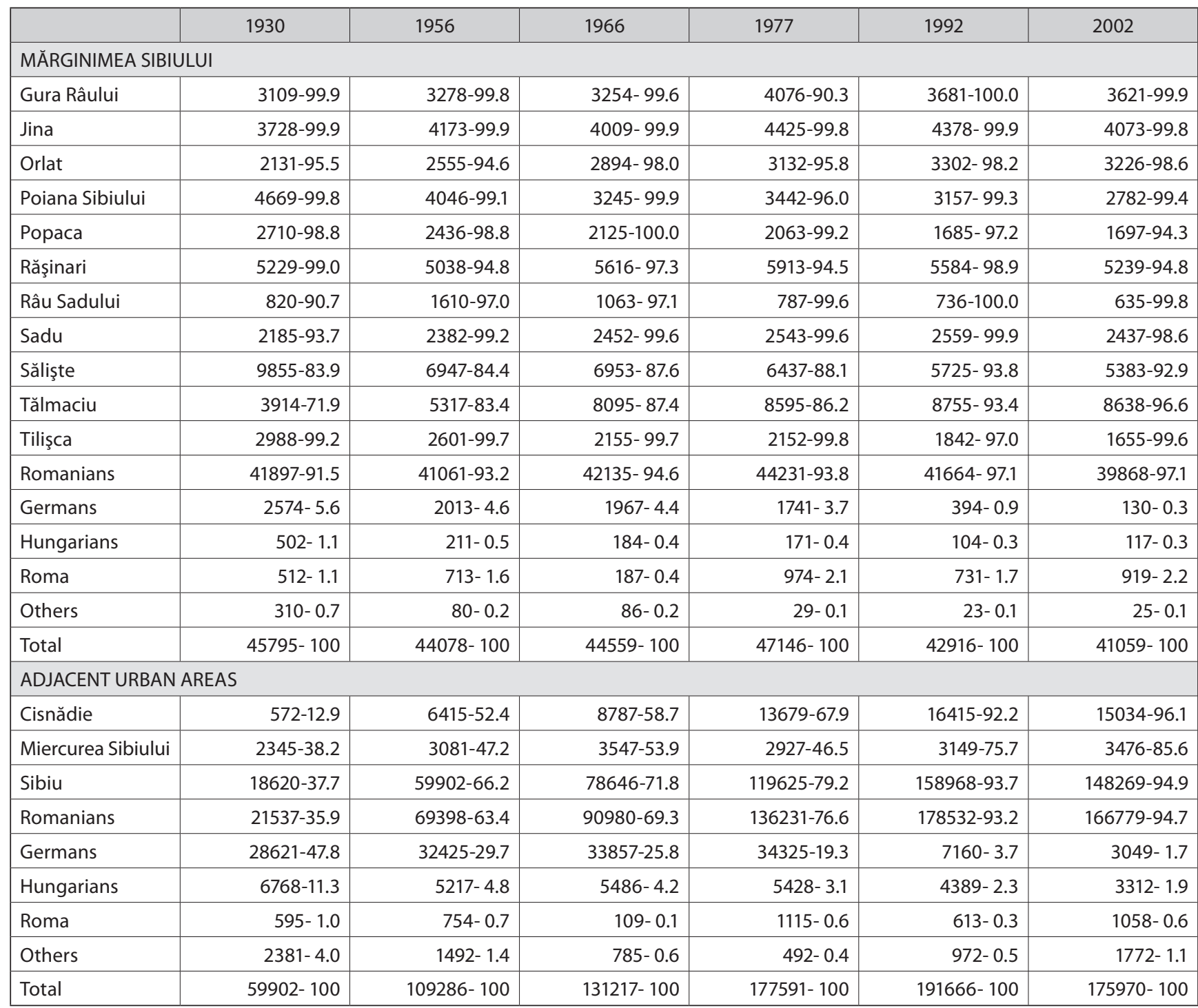


were only 32 in 1930 and 49 in 1992: they are actually to be found mainly in Prislop three kilometers away from the main settlement where they specialise in the production of brooms and baskets. However there were only 49 Roma in Prislop in 1992 when the majority chose to declare as Romanians! And while there are generally no Roma in Sadu, there were 84 in 1930 and 31 in 2002. Forestry work accounted for the 98 Germans in Râu Sadului in 1956; also 52 'others' in this commune in 1930, falling to 18 in 1956 but 26 in 1966 (mainly Ukrainians). Cisnădie has a profile of great ethnic variety with 35 'others' in 1930, 55 in 1956 and 44 in 1966, before falling to 17 in 1977, 161992 and 19 2002. Also Tălmaciu, with 181 in 1930 but only 28 in 1956 and 22 in 1966; then five in 1977, nine in 1992 and ten in 2002 .

\section{Conclusion}

Thanks to a relatively rich documentation for the Sibiu area of Romania it has been possible to discuss a range of salient features in the development of a Transylvanian Carpathian community that has maintained its ethnic character through centuries of life in the shadow of a large trading centre controlled by a highly privileged commercial community of foreign provenance. Yet despite some obvious discrimination, the Romanians of Mărginimea Sibiului adapted positively to the prevailing ecological and political conditions and built a successful pastoral economy combining the local grazings - offering high capacity during the summer months - with distant wintering grounds; and adapted to the constraints in modern times by partially resettling themselves across the Carpathians as part of the wider 'Ungureni' migration phenomenon. Meanwhile, for their part, the Saxon settlers demonstrated an enduring commitment to the region despite the radical nature of their introduction by the Medieval Hungarian state. And despite the setbacks arising from the Second World War and its aftermath - transportation to the Soviet Union, communist nationalisation and resettlement in Western Germany - there is still a community large enough to exercise political leadership and to reinforce the industrial base through stimulation of foreign direct investment by Austrian and German companies. So while the dualism once so evident in the dichotomy between the Saxon urban core and the Romanian rural hinterland has been drastically modified, the historic theme of coexistence and reciprocity is evolving into new forms as Sibiu's recent designation as Romania's 'City of Culture' evokes a response from the Carpathian rural fringe where authentic rural traditions can boost the potential for rural tourism and provide a complementary basis for a sustainable economy in the future.

\section{Acknowledgement}

We are grateful to K.Mori, S.Shirasaka and K.UrushibaraYoshino for permission to reproduce illustrations that appeared in the book editerd by K.Urushibara-Yoshino on 'Changing social conditions and their impacts on the geoecology: transhumance regions of Romania and Slovenia' (Tokyo: Hosei University Department of Geography) based on research funded in Japan by the Ministry of Education, Culture, Sports, Science \& Technology.

\section{References}

Akeroyd, J. 2006. The historic countryside of the Saxon villages of southern Transylvania (Saschiz: Fundația ADEPT).

Anon 2007. Planul local de acțiune pentru mediu (Sibiu: Județul Sibiu).

Badea, L., Buza, M. 1994. On the distribution of human settlements in the Cindrel and Şureanu Mountains. Revue Roumaine de Géographie 38, 109-14.

Badea, L., Caloianu, N., Dragu, G. 1971. Județele patriei: Județul Sibiu (Editura Academiei RSR).

Bugă, D., Dobre, S, 1996. Formarea rețelei de aşezări în Subcarpații Getici: considerații istorice şi toponomice. Studii şi Cercetări de Onomastică 2, 263-70.

Buza, M., Fesci, S. 1972. Studii geoecologice în etajele alpin şi subalpin din Munții Cindrel. Studii şi Cercetări de Geografie 19,1, 95-106.

Buza, M., Fesci, S. 1973. Condițiile ecologice si unele aspecte geografică ale păstoritului în Munții Cindrel. Studii si Cercetări de Geografie 20, 2, 189-96.

Buza, M., Fesci, S. 1983. Munții Cindrel (Bucharest: Editura Sport-Turism).

Buza, M. 1974. Considerații istorico-geografice asupra populației şi aşezărilor de la marginea Munților Cindrel. Studii si Cercetări de Geografie 21, 1, 69-81.

Buza, M. 1981. Das Alter und die Kontinuität der Bevölkerung im Şureanu und Cindrelgebirge und in den angrenzenden Gebieten. Revue Roumaine de Géographie 25, 1, 129-42.

Buza, M. 200o. Munții Cindrelului: studiu geoecologic (Sibiu: Editura Universităţii Lucian Blaga).

Buza, M. 2004. Mărginimea Sibiului: Păltiniş. Revista Geocarpathică 4, 227-38.

Caloianu, N. 1967. The industrial node of Sibiu. Revue Roumain de Géographie 11, 1, 91-7.

Caloianu, N. 1973. Structure fonctionelle des localités situées dans les Montagnes du Cindrel et ses zones environnantes. Analele Universității Bucureşti: Geografie 22, $105-7$.

Cojocariu-Costea, M. 2002. Turismul rural: element de bază în valorificarea peisajului geografic în Mărginimea Sibiului. Universitatea Romano-Germană Sibiu Buletin Ştiințific 1, 22-7.

Conea, I. 1965. Margini şi Mărgineni. Comunicăre de Geografie 3, 275-86.

Conea, I., Badea, L. 2004. Munții Mărginimi Sibiului: cadrul antropogeografic (Craiova: Editura Universitaria).

Constantin, M. 2003a. Retrospective historique de la transhumance chez les Roumains par rapport a la mémoire culturelle du village de Tilişca. Annuaire Roumain d'Anthropologie 39, 109-16.

Constantin, M. 2003b. Despre transhumanță şi economie de piață în satul Tilişca. Sociologie Românească 1, 3, 94-101. 
Constantin, M. 2004. Capitalism and transhumance: a comparison of three pastoral market types in Europe 1950-2000. New Europe College Yearbook 2003-2004, 57-116.

Cowell, M. 2006. Future land use change in a traditionally farmed landscape in Eastern Europe (Transylvania, Romania). Transylvanian Review of Systematic \& Ecological Research 3, 199-216.

Donat, I. 1966. Păstoritul românesc şi problemele sale. Studii: Revista de Istorie 19, 2, 282-99.

Dragomir, N. 1925. Din trecutul oierilor Mărgineni din Săliste şi comunele din jur. Lucrările Institutului de Geografie al Universității din Cluj (Timişoara) 2, 192-257.

Dragomir, N. 1938. Oierii mărgineni în Basarabia Caucaz Crimea şi America de Nord. Lucrările Institutului de Geografie al Universității din Cluj (Timişoara) 6, 159-303.

Florea, M. 1996. Riscul geomorfologic în etajul alpin din Munții Făgăraşului. Studii si Cercetări de Geografie 43, 137-42.

Ghinea, D. 1996-8. Enciclopedia geografică a României (Bucharest: Editura Enciclopedică) 3 vols.

Giurcăneanu, C. 1988. Populația și așezările din Carpații Românești (Bucharest: Editura Științifică și Enciclopedică).

Grecu, V.V. 1990. Sălişte Sibiului: străveche vatra românească (Sibiu: Astra).

Haşeganu, A. 1941. Mărginenii în viața economică a Transilvaniei şi vechiului regat (Braşov: Tipografia Minerva).

Haşeganu, A. 1942. Evoluția şi importanța economică a rețelei hidrografice din Sibiu. Lucrările Institutului de Geografie al Universitătii din Cluj (Timişoara) 7, 207-27.

Iacob, G. 1962. Considerații asupra agriculturii în Depresiunea Sibiului. Natura: Seria Geografie-Geologie 2, 28-36.

Iacob, G. 1991. Valorificarea patrimoniului forestier al Carpaților Meridionali: sectorul dintre Olt și Jiu. Academia Română Memoriile Secțiilor Științifice 10,1, 301-7.

Irimie, C., Dunare, N., Perescu, P. eds. 1985. Mărginenii Sibiului: civilizație şi cultura populară românească $(\mathrm{Bu}-$ charest: Editura Ştiințifică și Enciclopedică).

Jones, A. 2007. The challenge of high nature value grasslands conservation in Transylvania (Romania). Transylvanian Review of Systematic \& Ecological Research 4, 73-82.

Lotreanu, I. 1988. Sadu: Studiu monografic şi etnomuzicologic (Bucharest: Editura Alternative).

Miclea, I. 1983. Răşinari (Sibiu: Zeitschrift Transylvania).

Moga, I. 1944. Les Roumains de Transylvanie au Moyen Age (Sibiu: n.p.).

Moga, I. 1973. Scrieri istorice 1926-1946 (Cluj: Editura Dacia).

Pop, G.P. 1996. România: geografie hidroenergetică (ClujNapoca: Presa Universitară Clujeană).

Possa, M., Mihalik, P. 1966. Poiana Sibiului: complex de arhitectura populară (Bucharest: Editura Meridiane).
Rotariu, T., Semeniuc, M., Mureșan, C. 1997. Studia censualia Transsilvanica: recensământul din 1880 (Cluj-Napoca: Editura Staff).

Rotariu, T., Semeniuc, M., Pah, I., Mezei, E. 1998, Studia censualia Transsilvanica: recensământul din 1857 (ClujNapoca: Editura Staff).

Shirasaka, S. 2006. The transhumance of sheep in the Southern Carpathian Mountains, Romania. K.UrushibaraYoshino ed., Changing social conditions and their impacts on the geoecology: transhumance regions of Romania and Slovenia (Tokyo: Hosei University Department of Geography), 76-103.

Shirasaka, S. 2007. The transhumance of sheep in the Southern Carpathian Mountains, Romania. Geograph ical Review of Japan 80, 5, 94-115.

Stewart, M. 1997. We should build a statue to Ceauşescu here: the trauma of decollectivisation in two Romanian villages: S. Bridger \& F. Pine eds., Surviving post-socialism: local strategies and regional responses in Eastern Europe and the Former Soviet Union (London: Routledge), 66-79.

Turnock, D. 2003. Settlement and sustainability in the Carpathians: pre-modern settlement history with particular reference to the role of pastoralism in Romania: Analele Universității de Vest din Timişoara: Geografie 13, 91-114.

Urushibara-Yoshino, K., Mori, K. 2007. Degradation of geoecological and hydrological conditions due to grazing in the south Carpathian Mountains under the influence of changing social structure in Romania. Geographical Review of Japan 80, 5, 76-93.

Velcea, V. 1998. Natural and man-induced hazard factors in the southern Carpathians: G. Erdeli \& D. Dumbrăveanu eds., Romanian-British Geographical Exchanges: Proceedings of the Third Romanian-British Colloquium (Bucharest: Corint), 195-8.

Vlad, S., Vişan, G. 1996a. Aspects toponymiques qui reflétent l'activité pastorale dans les Carpates Méridionales: G.Niculescu \& C.Muică eds., Carpates Méridionales et Stara Planina: Études Géographques (Bucharest: Academia Română Institutul de Geografie), 142-50.

Vlad, S., Vişan, G. 1996b. Le défrichage et son reflet dans la toponymie des montagnes entre l'Olt et le Jiu. G.Niculescu \& C.Muică eds., Carpates Méridionales et Stara Planina: Études Géographques (Bucharest: Academia Română Institutul de Geografie), 151-5.

Voicu-Vedea, V. 1998. Mărginimea Sibiului: studiu de geografie rurală (Sibiu: Editura Universitatea 'Lucian Blaga' Sibiu).

Vuia, R. 1964. Tipuri de păstorit la români (Bucharest: Editura Academiei RSR).

Wagner, E., 1977. Historisch-statisches Ortsnamenbuch fŭr Siebenbŭrgen (Köln/Wien: Böhlen Verlag) 